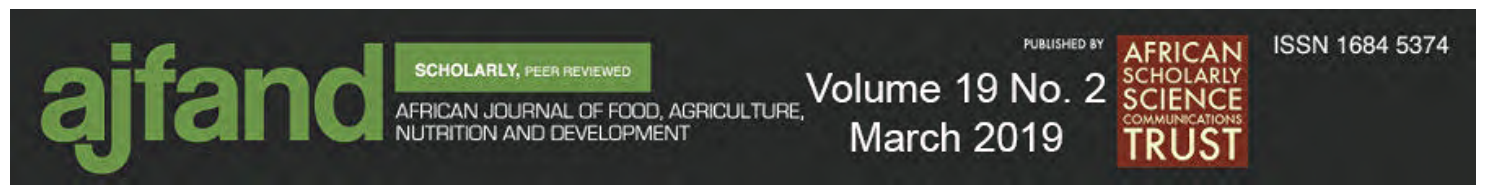

Afr. J. Food Agric. Nutr. Dev. 2019; 19(2): 14432-14457

DOI: 10.18697/ajfand.85.17205

\title{
WOOD UTILIZATION EFFICIENCY AND ACCEPTABILITY OF FRIED AND SMOKED FISH FROM LAKE MALAWI
}

Makawa $Z^{1}$, Kaunda $E^{2}$ and $F$ Kapute ${ }^{3 *}$

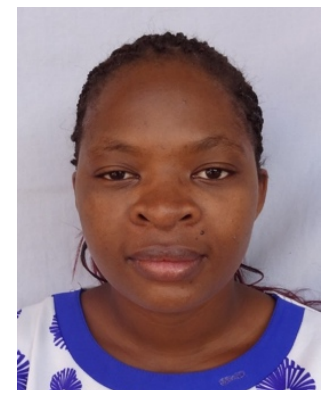

Zione Makawa

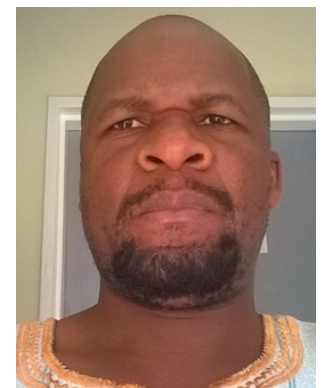

Fanuel Kapute

*Corresponding author email: fkapute@gmail.com

${ }^{1}$ Master of Science Degree Student, Department of Aquaculture and Fisheries Science, Lilongwe University of Agriculture and Natural Resources, Bunda College Campus, P.O. Box 219, Lilongwe, Malawi

${ }^{2}$ Professor in Fisheries Science, Department of Aquaculture and Fisheries Science, Lilongwe University of Agriculture and Natural Resources, Bunda College Campus, P.O. Box 219, Lilongwe, Malawi

${ }^{3}$ Associate Professor in Fish Quality Management, Department of Fisheries and Aquatic Science, Mzuzu University, Private Bag 201, Luwinga, Mzuzu 2, Malawi 


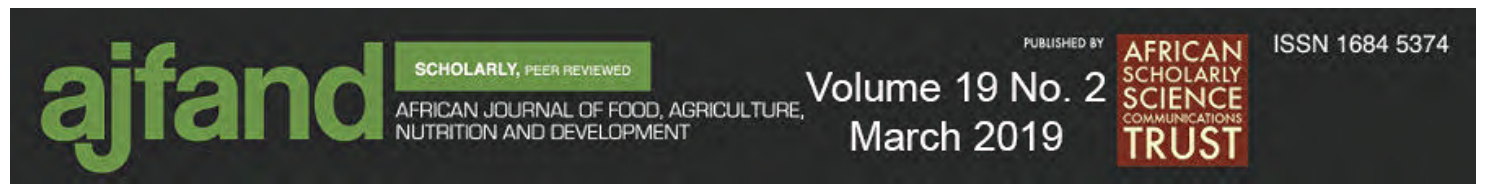

\begin{abstract}
Processing fish and fish products ensures longer shelf life, reduced post-harvest losses, better nutrition and organoleptic qualities, and attracts better market prices. However, traditional smoking, which is a common fish processing method in Malawi, is becoming difficult due to the huge volumes of wood used in the face of rapid loss of forests. Recently, fish processors have also started frying freshly caught fish as a way of processing before sale. This study compared the efficiency of wood utilization between the traditional smoking kiln, the Food and Research Institute smoking kiln (FRISMO), the modified smoking kiln and frying for Engraulicypris sardella and Copadichromis species. The processed fish were tested for consumer acceptability. The amount of wood for smoking Copadichromis species was $0.98,1.24,1.42$ and $1.84 \mathrm{~kg} / \mathrm{kg}$ of fish processed with the modified, FRISMO, traditional kilns and frying, respectively. These values were, however, not significantly different $(\mathrm{P} \geq 0.05)$. More wood $(\mathrm{P}<0.05)$ was used in frying E. sardella $(5.83 \mathrm{~kg} / \mathrm{kg})$ than FRISMO (1.01), modified (0.98) and traditional kilns (1.81). Mean sensory scores of smoked Copadichromis species (7.4 \pm 0.2$)$ and E. sardella $(7.0 \pm 0.2)$ were higher in the modified kiln $(\mathrm{P}<0.05)$ than the FRISMO $(6.2 \pm 0.2$ and $7.3 \pm 0.2)$ and the traditional kiln $(7.0 \pm 0.2$ and $6.1 \pm 0.2)$, respectively. Sensory scores were significantly higher $(8.3 \pm 0.2)$ and $(7.9 \pm 0.2)(\mathrm{P}<0.05)$ for fried Copadichromis species and E. sardella, respectively, than those for the smoking methods (FRISMO (6.2 \pm 0.2 ), modified kiln (7.8 \pm 0.2 ), traditional kiln (7.0 \pm 0.2$)$ for E. sardella and FRISMO (7.3 \pm 0.2$)$, modified kiln (7.9 \pm 0.2 ), and traditional kiln (6.1 \pm 0.2$)$ for Copadichromis species). It is concluded that the modified kiln followed by the FRISMO kiln are more economical in terms of wood use efficiency as compared to frying. Fried fish, however, is highly acceptable by consumers compared to smoked fish. Based on the study results, mass adoption of less wood demanding fish processing methods such as the use of the modified and FRISMO kilns could help in reducing deforestation and should be promoted among fish processors.
\end{abstract}

Keys words: Smoking, frying, Copadichromis species, Engraulicypris sardella, wood usage 


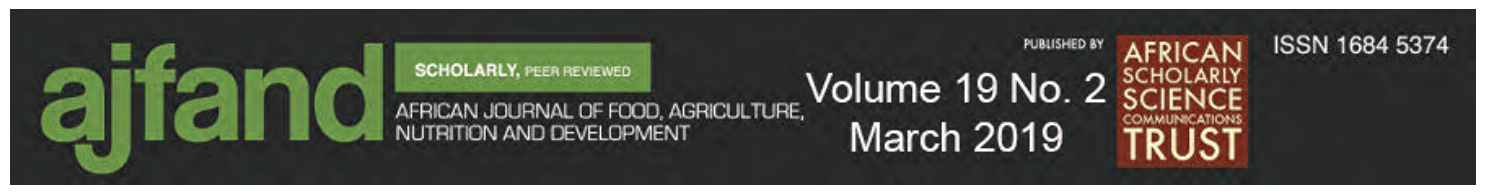

\section{INTRODUCTION}

High fish post-harvest loss is undermining the growth of the fisheries businesses in the face of unstable and declining fish catches. In Malawi, fish post-harvest losses are estimated to be as high as $40 \%$ during the rainy season [1]. And it is evident that current post-harvest fish management practices that are in use are not efficient. Fish smoking, which is by far the most common method of processing fresh fish in Malawi is one of the major drivers of deforestation and consequently is contributing to climate change [2]. Smoked fish, however, have a prolonged shelf life, better flavour and higher economic value. Smoking is probably the best way of processing fresh fish to reduce wastage in times of bumper catches that usually coincide with the rainy season when sun-drying is slowed by high humidity and cloud cover $[3,4]$. The Food Research Institute improved smoking oven (FRISMO), adapted from West Africa, is, based on research, the only efficient smoking kiln being used in Malawi [5]. The FRISMO kiln has recently been modified to use less wood to minimize challenges faced by fish processors [5]. The FRISMO kiln has been successfully introduced and adopted in Lake Chilwa resulting in a reduction of $30 \%$ wood use as well as better preserving the quality of African catfish (Clarias gariepinus) and matemba (Barbus species) [5]. However, fish processors could not adopt the technology because of its bigger size which made its use difficult as it demands more than one person to handle the trays. The other challenge is that it is stationary hence lack of flexibility of moving it when changing fish processing site or during floods along the lake. It is thus, an inefficient technology especially to mobile fish processors who usually dominate the beaches of Lake Malawi.

In order to solve the above stated challenges, the modified kiln was fabricated for use in this study. The modified kiln was made to be mobile by replacing bricks with metal. The trays in the new modified kiln were also made of metal to improve heating during processing of the fish. The size of the kiln was made smaller than the FRISMO kiln to allow one person to operate and handle smoking trays with minimum challenges during processing. It has a provision for small openings below the fire chamber to allow free air circulation and escape of ash during smoking. Consideration was also made on size, shape and form of the kiln. The kiln was made to be enclosed in form and rectangular in shape to improve heating as it is recommended by $[6,7]$.

Again, the modified smoking kiln is more cost effective and has a longer shelf life. In the quest to increase storage time, consumer acceptance and commercial value of the processed fish, processors in some areas around Lake Malawi have recently been frying freshly caught fish before selling. Fried fish have now become more popular among consumers than smoking [8]. However, the method appears to pose health and nutritional hazards to consumers. For example, the method promotes the production of more polycyclic aromatic hydrocarbons (PAH), which are carcinogenic [9]. Further, the high temperature involved in frying may degrade nutrients through hydrolysis and oxidation of the fatty acids [9]. The oil used in the frying of the fish is heavily recycled and often dirty. Studies also suggested that exposure to cooking oil used to fry food including fish increases the risk of diseases such as cancer [10]. Above all, fish frying as a processing method in Malawi gives lower quality end products (personal observation). Consequently, these methods are used on small species Engraulicypris sardella and 


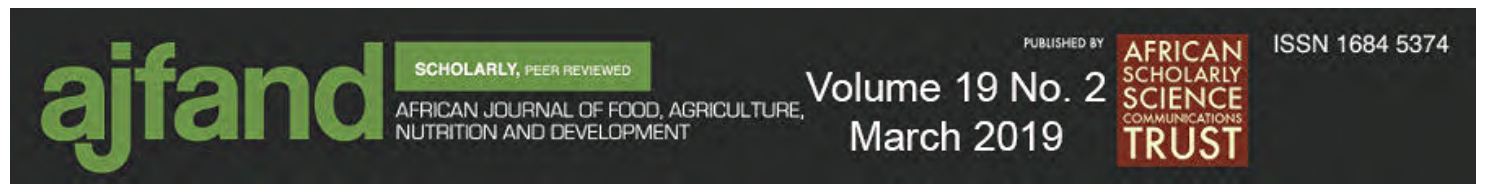

Copadichromis species and currently these species make up the larger part of fish catches from Lake Malawi. These species are also highly affected by post-harvest loss as their catches are huge during the rainy season and the fish are rarely consumed fresh hence needs to be processed even when the weather is not friendly.

The objective of the study was to determine wood use efficiency and the acceptability of products from the FRISMO, modified and traditional kilns as well as the frying method evaluated with Engraulicypris sardella and Copadichromis species. The present study was intended to provide a possible solution to some of the challenges faced with smoking and add more information about the quality aspects of frying.

\section{MATERIALS AND METHODS}

\section{The Study Sites}

The study was carried out at the Bunda College Campus of the Lilongwe University of Agriculture and Natural Resources where both smoking and frying trials as well as laboratory work was done. The trials were also done at Nkhotakota Fisheries Department beach station. The beach is in the Linga Extension Planning Area of the Nkhotakota district in the central region of Malawi. Nkhotakota lies at an elevation of 1,550 feet (472 $\mathrm{m}$ ) on the shores of Lake Malawi, Malawi. The fishery in Nkhotakota, like the whole of Lake Malawi, has been heavily hampered by over-fishing, and the effects of climate change, such as temperature and increased rainfall variability. Fish catch composition has changed and there is increased production of small species (usipa - Engraulicypris sardella, kambuzi - Nyassachromis spp. and utaka - Copadichromis spp.), which have recently doubled.

\section{Construction of smoking kilns}

Three types of smoking kilns: FRISMO, modified and traditional were fabricated and constructed at the beach station.

\section{The Food Research Institute improved smoking (FRISMO) kiln}

The kilns were constructed using bricks on the outer part with a metal framework inside as shown in Figure 1. The internal metal framework was made of angle iron ( $25^{\prime \prime}$ by $25^{\prime \prime}$ by $3^{\prime \prime)}$ and the doors and the chimney were made of galvanized sheet metal $(1.2 \mathrm{~mm})$. The smoking trays were made of hardwood on the sides and chicken wire made from stainless steel as its base. The dimensions of the kiln were: Base: $2.2 \mathrm{~m}$, height: $1.68 \mathrm{~m}$, fire hole: $29 \times 26 \mathrm{~cm}$, door frame: $1.7 \times 1 \mathrm{~m}$. 

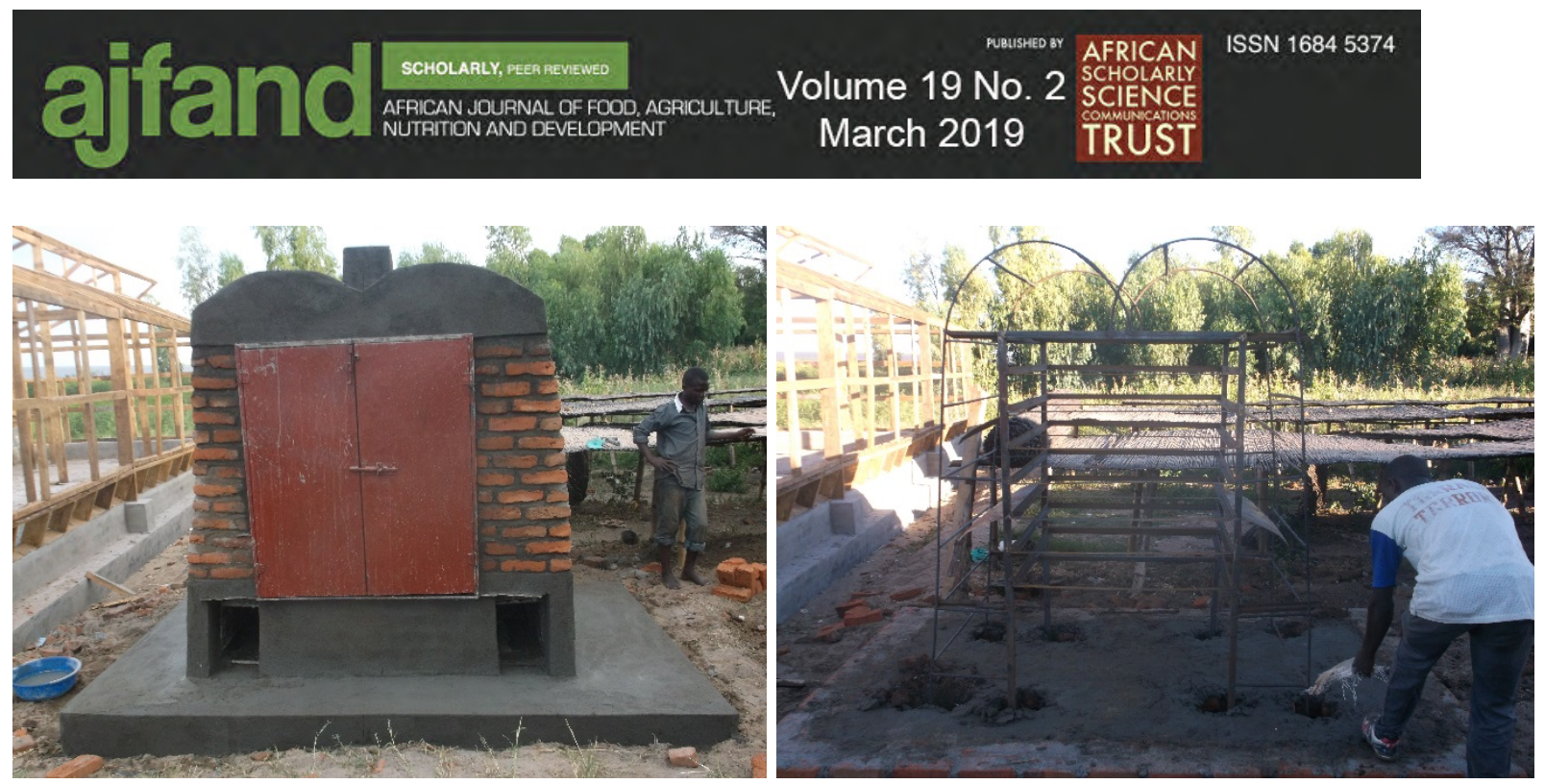

Figure 1: Completed FRISMO kiln (left) and the inside metal framework (right)

Seven racks were made within the smoking chamber where trays are placed during smoking. The smoking trays were $0.9 \times 0.9 \mathrm{~m}$ and two kilns were constructed for the study.

\section{The modified kiln}

The "modified kiln" was a modification of the FRISMO kiln which aimed at solving the shortfalls that restrict fish processors from adopting the FRISMO kiln. The Modified smoking kiln was fabricated using metal and made to be mobile by replacing bricks with metal so that fish processors and other users can move it indoors or to a shady place when it rains or when the beach is flooding. The internal metal framework was made of angle iron on which the entire component of the kiln was assembled. Corrugated heavy iron $(1.5 \mathrm{~mm})$ was used to make the outer framework of the kiln. The metal framework had removable trays like the FRISMO kiln. Heavy iron and stainless steel were used to make the fish smoking trays, which improved the heating during processing of the fish unlike in the FRISMO kiln where mesh wire is used. The size of the kiln was reduced to allow one person to easily operate and handle smoking trays. A metal door was designed to open from the front side for loading and unloading as well as closing the kiln to promote heat retention inside during smoking. The fire chamber below the door towards the front was made with holes to allow free air circulation and release of ash during smoking. On the other hand, in the FRISMO kiln, there is a provision of two holes on the sides of the kiln through which firewood is inserted. The top part of the kiln was closed off with a chimney to allow escape of smoke (Figure 2). 

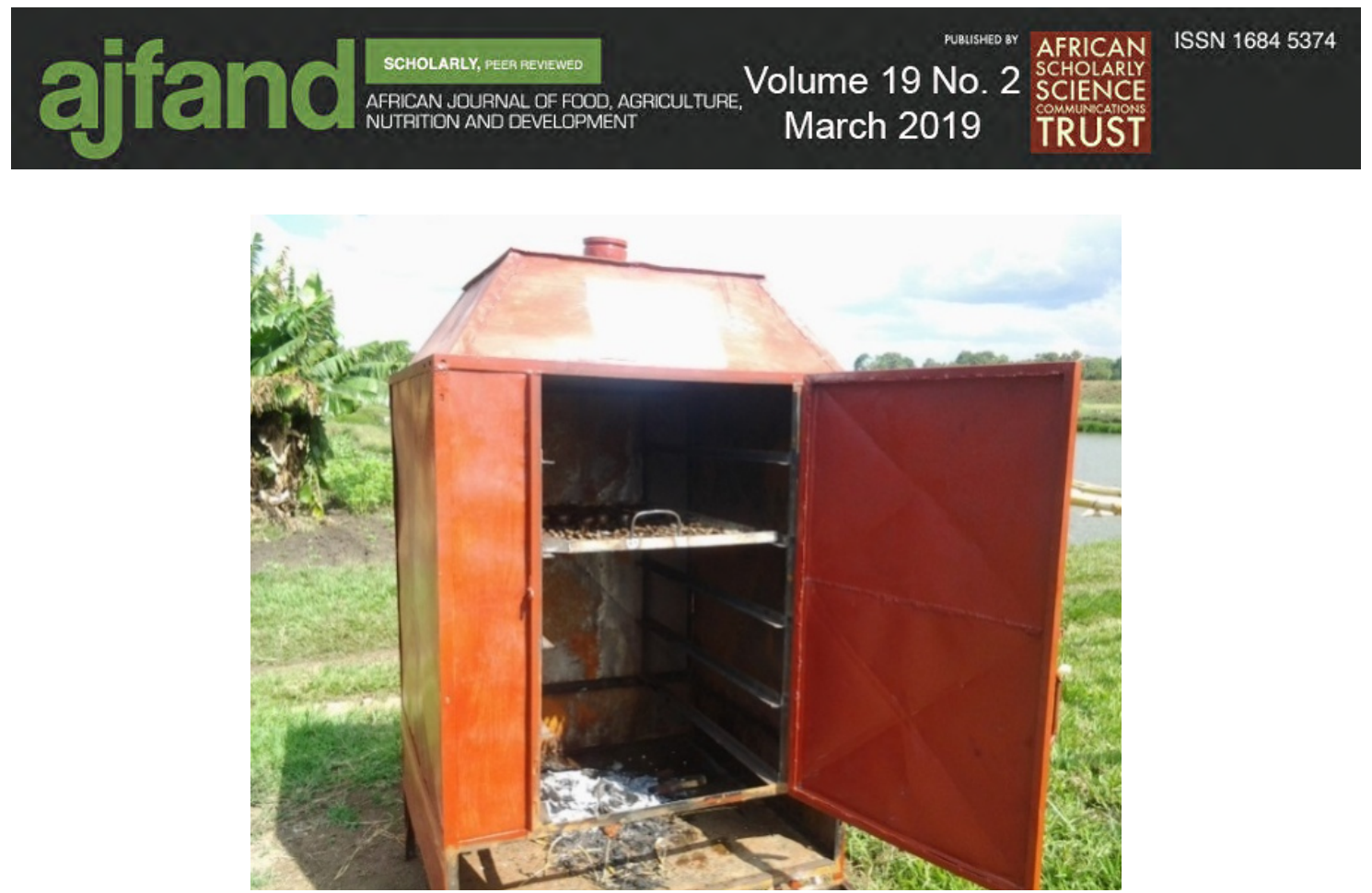

Figure 2: The modified fish smoking kiln

The smoking chamber held 5 tiers of trays made from mild steel $(1.2 \mathrm{~mm})$ with 4 legs to raise it from the ground for free circulation of air during smoking and to allow it be stable when in use.

\section{The traditional smoking kiln}

The traditional kiln (Figure 3) was made of burnt mud bricks and mud. A separate plywood cover coated with iron sheet $(0.55 \mathrm{~mm})$ on its outer bottom part was used as a cover for the fish smoking trays to cover the fish during smoking. The smoking trays were made of plywood as well and mesh wire as its base. The dimensions of the kiln as shown in Figure 3 were: $90.5 \mathrm{~cm}$ long and $90.5 \mathrm{~cm}$ wide, fire hole: $29 \mathrm{~cm}$ by $26 \mathrm{~cm}$.
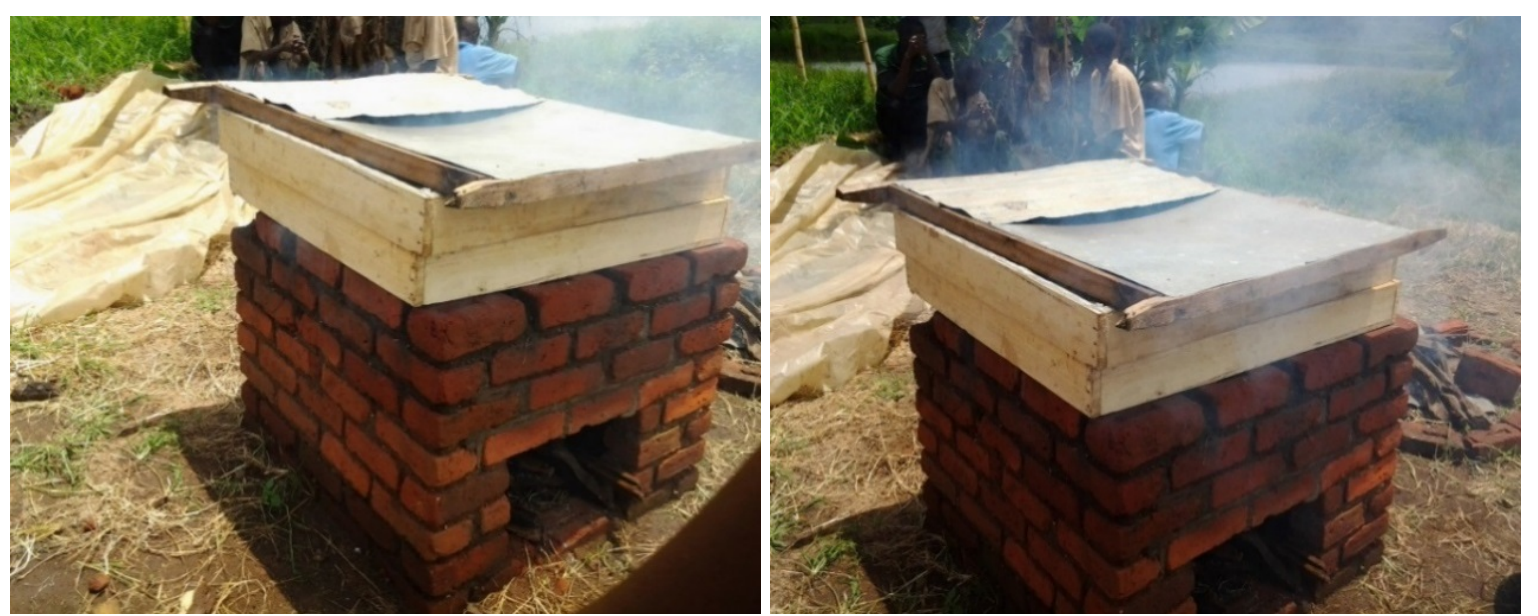

Figure 3: The traditional smoking kiln

\section{Determination of wood usage}

Fish smoking and fish frying studies were done using E. sardella with an average weight of $5 \mathrm{~g}$ and Copadichromis species with an average weight of $15 \mathrm{~g}$, the most common species currently caught by artisanal fishers (Figure 4). The fish was caught using trawlers, cleaned and immediately placed in ice for transportation. Upon reaching the 


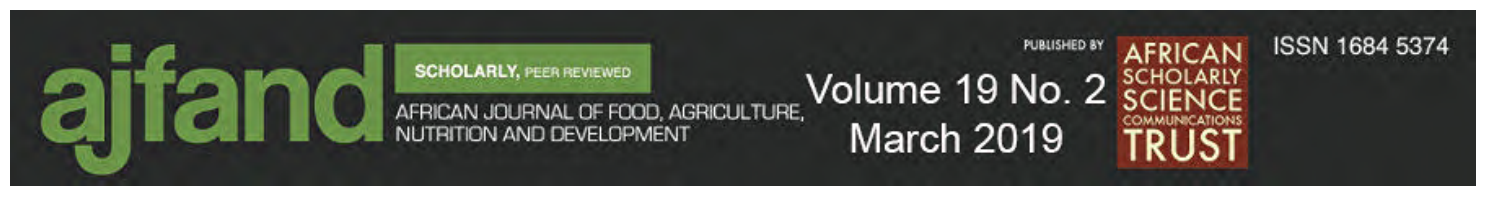

study site, they were weighed and semidried for about five minutes under the temperature of $25^{\circ} \mathrm{C}$.
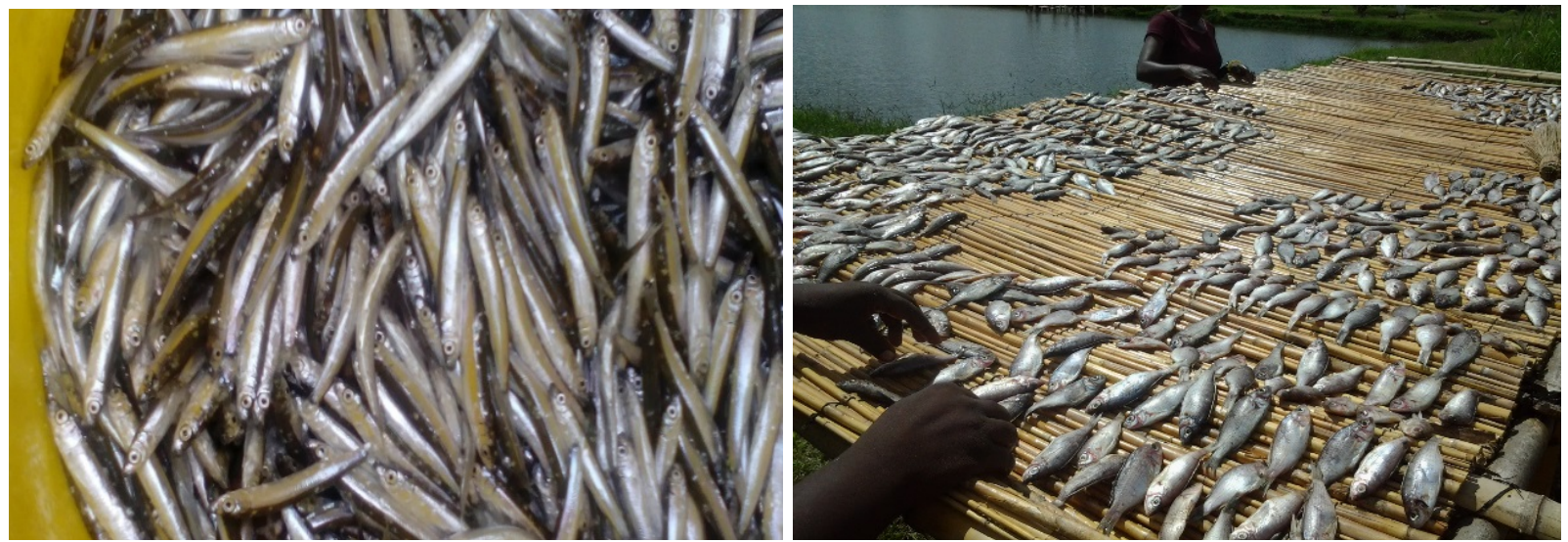

Figure 4: Fresh Engraulicypris sardella (left) and Copadichromis species (right)

During smoking, the kilns were loaded with semi-dried fish. The FRISMO kiln was loaded with $31.5 \mathrm{~kg}$ of Copadichromis species at a time, with $4.5 \mathrm{~kg}$ of fish on each tray and $35 \mathrm{~kg}$ of the Engraulicypris sardella at a time. The modified kiln was loaded with $20 \mathrm{~kg}$ of Engraulicypris sardella and $17.5 \mathrm{~kg}$ of Copadichromis species. For the traditional kiln, 8kg of Engraulicypris sardella and 13kg of Copadichromis species were loaded at a time for processing.

Moisture and fat contents of the fresh fish were determined prior to the smoking and frying of the fish using methods by Association of Official Analytical Chemists [11] (Table 2).

Dry hardwood from Pericopsis angolensis tree (locally known as Muwanga) was used for frying and smoking of the fish in this study (Figure 5).

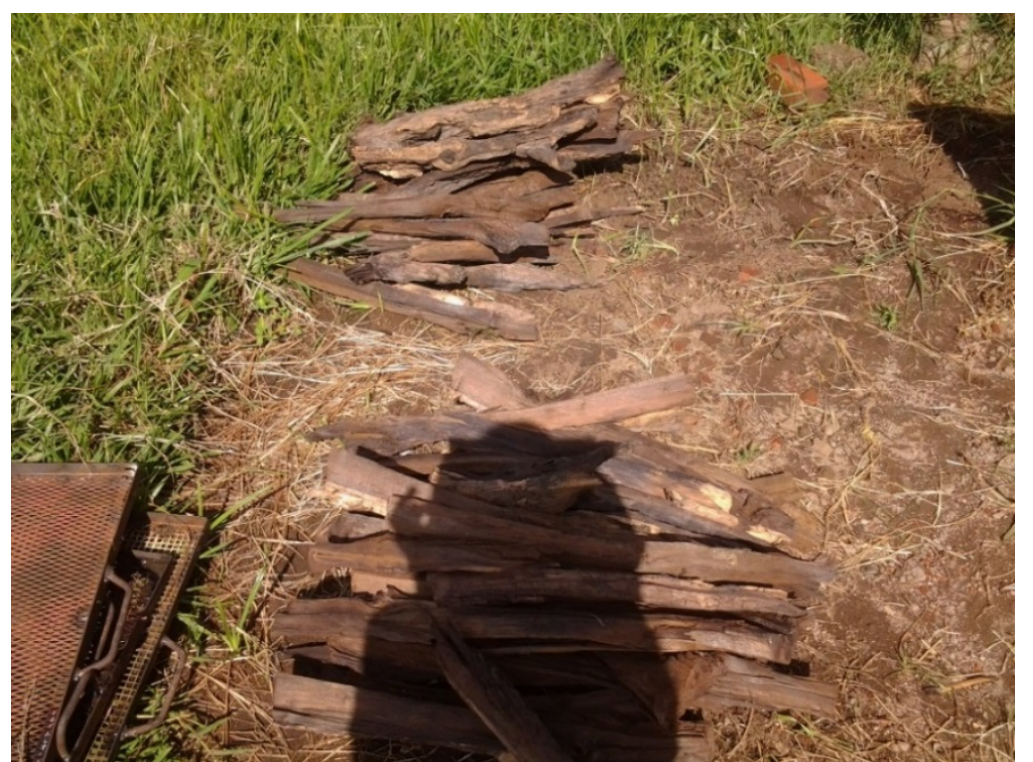

Figure 5: Dry hardwood from Pericopsis angolensis tree used for smoking of the fish 


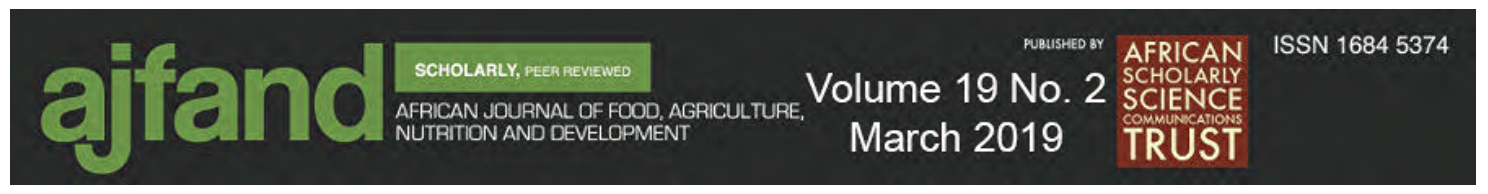

P. angolensis (local name: Muwanga) is one of the woods that are used for fish smoking in Malawi, especially in the Nkhotakota district, where the study was done and where it is readily available. The wood preferences of most fish smokers are also related to the physical characteristics of the wood and how they affect the smoked product. $P$. angolensis wood is denser, burns slowly with high heat and produces a flavour that is pleasant. It imparts good aroma and gives fish products a rich brown-golden colour.

Smoking and frying studies were done 3 times with different fish in the months of August and September. During smoking, the temperature was maintained between 52 and $73^{\circ} \mathrm{C}$ in all kilns to achieve hot smoking. Depending on the efficiency and stability of temperature in the different kilns, the time taken for fish to get smoked was obtained and this was compared with how many kgs of fish were processed within that period. The fish was declared smoked when the appearance of the smoked fish was golden brown in colour and glossy in appearance, desirable in texture, appealing smoky aroma and after checking that it had attained the desired weight loss as predetermined prior to the experiment. Data on quantity of firewood used was collected during smoking and frying. To determine the amount of wood used by each kiln, the actual weight of the wood used for smoking was calculated by obtaining the difference between the total weight of wood loaded into the smoking kiln and the weight of unconsumed wood after smoking. To calculate differences in the fire wood usage of the other kilns (method 2) against the traditional kiln (method 1), the formula below was used [12]:

Av wt. of wood used $/ \mathrm{kg}$ for Method 1 - Av wt. of wood used $/(\mathrm{kg}$ for Method $2 * 100)$

Av wt. of wood used $/ \mathrm{kg}$ for Method 1

Frying (Figure 6) was done at $190^{\circ} \mathrm{C}$. A frying pan was used for frying and a $\mathrm{Kg}$ of fish was placed at a time in hot edible vegetable cooking oil for frying. Initially, 5 litres of cooking oil was placed on fire but not all of it was drained during frying. Cooking oil was changed when the level in the pan changed to achieve deep frying for all samples. The quantity of wood used with the open fire was measured as previously. 

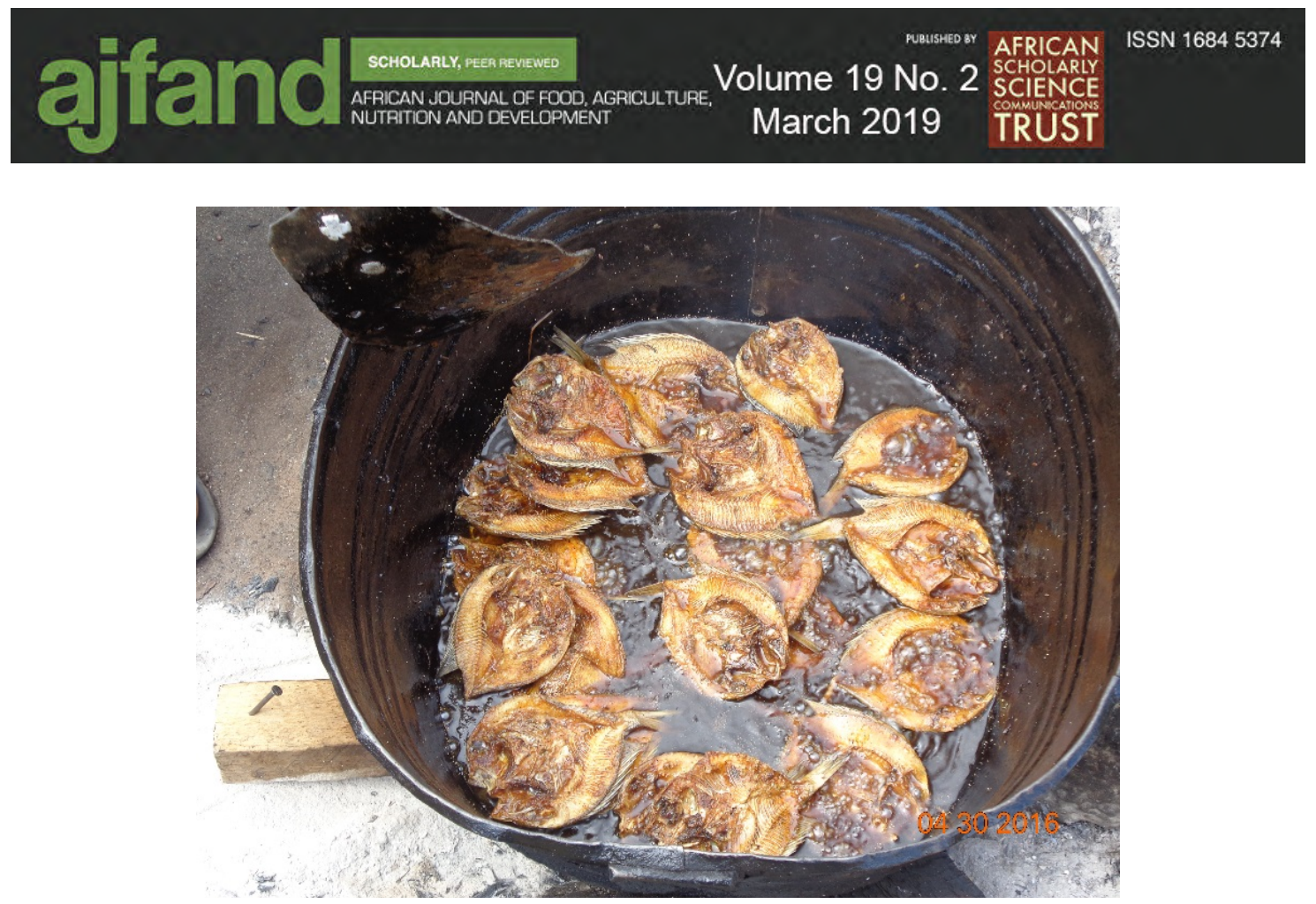

Figure 6: Fish frying

\section{Acceptability of processed fish products}

Organoleptic tests for fish smoked (Figures 7 and 8) were carried out using a group of 40 pre-trained assessors, $50 \%$ of which were male and the other $50 \%$ were female. The team also combined University students, workers as well as relatives to the university workers.
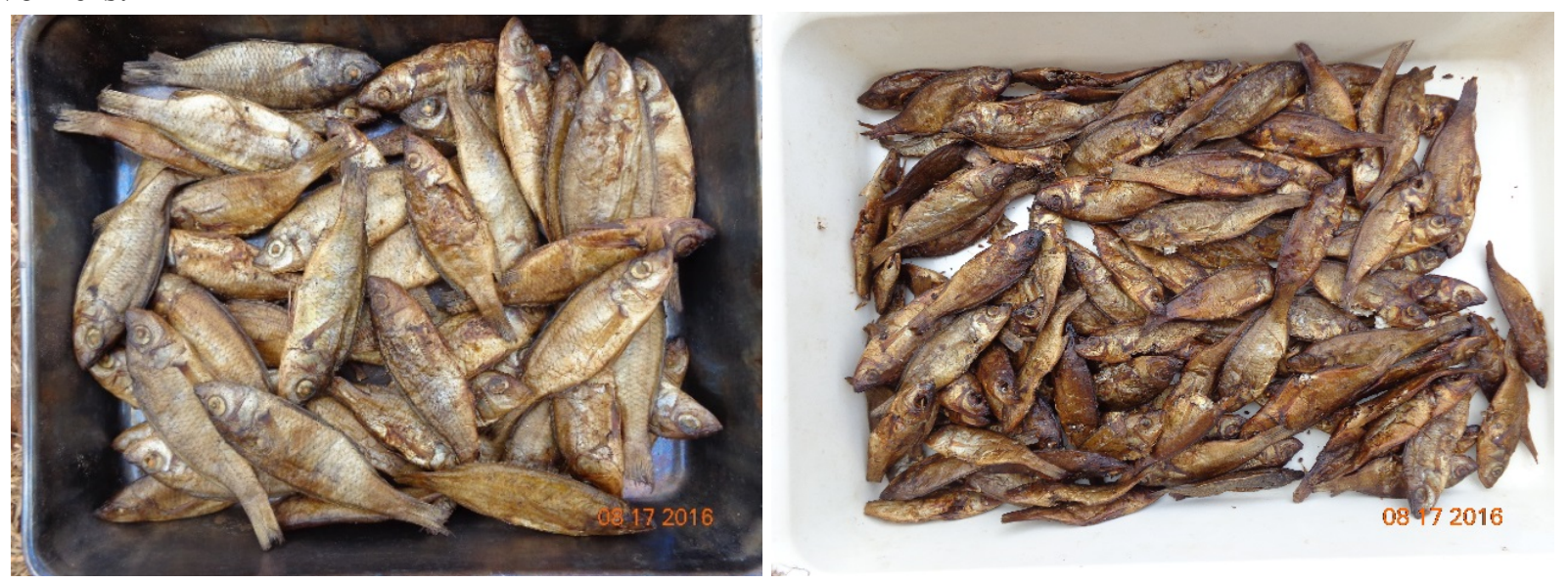

Figure 7: Copadichromis species smoked in the modified kiln (left) and Traditional kiln (right) 

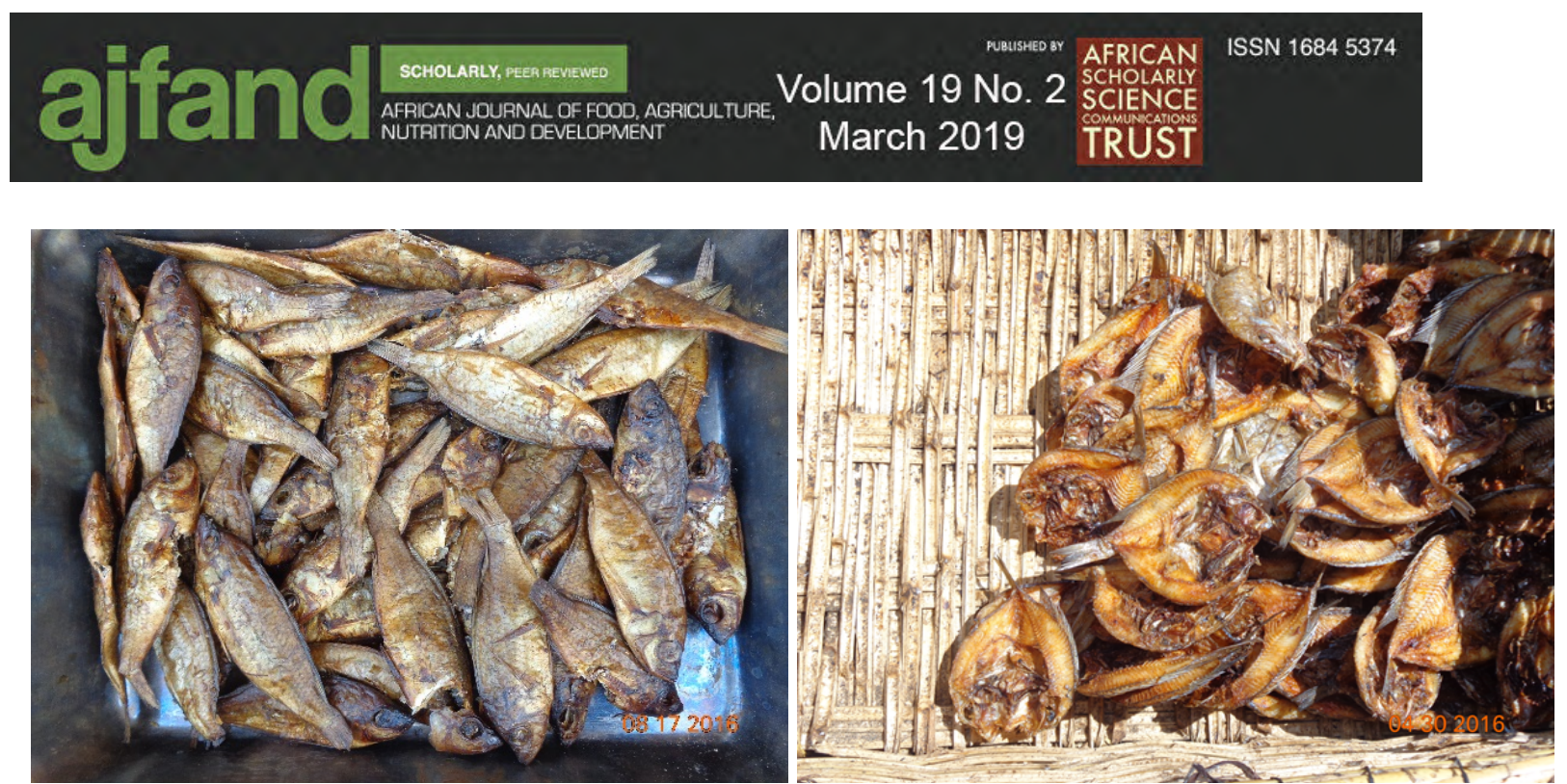

Figure 8: Copadichromis species smoked using the FRISMO kiln (left) and frying (right) method

Qualitative descriptive analysis (QDA) of the organoleptic properties for the processed fish products was used for assessment on a nine-point hedonic scale summarized as follows: 1 - dislike extremely, 2 - dislike very much, 3 - dislike, 4 - dislike slightly 5 neither like nor dislike, 6 - like slightly, 7 - like, 8 - like very much, 9-like extremely [13].

The viability of using each method was also assessed. This involved quantifying all the benefits (income) and costs that were incurred in the construction, fabrication and use of each smoking kiln and the frying technology for both E. sardella and Copadichromis species. Assumptions as presented in Table 3 were made in computing cost benefit analysis.

A cost benefit ratio was then calculated for financial assessment. Some of the major formulae that were used were:

Gross returns: Total benefit - Total Costs

Cost benefit ratio

Where:

$\left(\sum \mathrm{Bt} /(1+\mathrm{r}) \mathrm{t} /(\mathrm{Ot} /(1+\mathrm{r}) \mathrm{t})+\mathrm{K}, \mathrm{B}_{\mathrm{t}}=\right.$ discounted benefits, $\mathrm{Ot}=$ discounted costs, $1 /(1+\mathrm{r}) \mathrm{t}=$ discounting factors, $r=$ interest factor, $\mathrm{t}=$ no. of years and $\mathrm{K}=$ investment capital.

Net present value

$\mathrm{NPo}=\mathrm{Y} 1 /(1+\mathrm{r}) 1+\mathrm{Y} 2 /(1+\mathrm{r}) 2+\cdots+\mathrm{Yn} /(1+\mathrm{r}) \mathrm{n}-\mathrm{C}$

Where:

$\mathrm{Yi}=$ net cash revenue flows, $\mathrm{C}=$ original investment cost, $\mathrm{r}=$ discounting rate and payback period $=$ initial payment/annual cash inflow

\section{Statistical analysis}

Descriptive analysis was used to analyze sensory results. One-way analysis of variance (ANOVA) was carried out to compare means $(\mathrm{P}<0.05)$ in the wood usage and acceptability of products from different processing methods. Significantly different means were separated using Turkey test. Data were analyzed using SPSS for Windows Version 20.0. For financial analysis, excel was used to calculate the cost benefit ratios using the formulae earlier presented. 


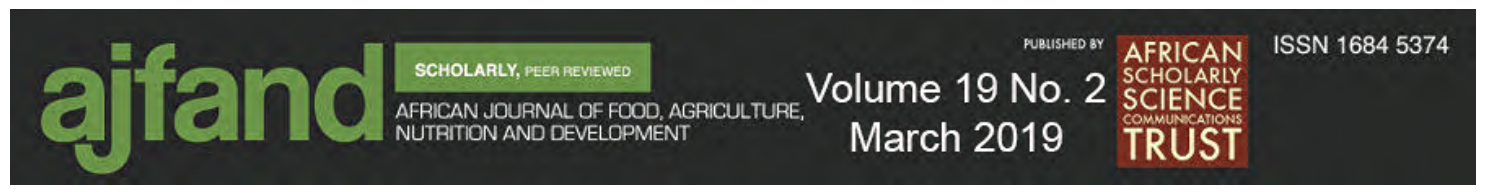

\section{RESULTS}

\section{Wood utilization efficiency}

Results for wood utilization efficiency for different fish processing methods are shown in Table 4. Quantity of wood used to process a $\mathrm{kg}$ of E. sardella differed significantly $(\mathrm{P}<0.05)$ among the methods while for Copadichromis species, the amount of wood was not significantly different among the methods $(\mathrm{P}>0.05)$. For $E$. sardella, frying used significantly higher quantity of wood $(5.83 \mathrm{~kg}$ wood $/ \mathrm{kg}$ fish processed $)(\mathrm{P}<0.05)$ than the smoking methods (traditional, FRISMO and modified kilns).

Among the smoking methods, the traditional kiln used significantly higher amount of wood $(1.81 \mathrm{~kg}$ wood $/ \mathrm{kg}$ fish processed) for smoking E. sardella $(\mathrm{P}<0.05)$ than the FRISMO $(1.01 \mathrm{~kg})$ and the modified kiln $(0.98 \mathrm{~kg})$. However, the amount of wood used by the FRISMO and the modified kilns to process a $\mathrm{kg}$ of E. sardella was not significantly different $(\mathrm{P}>0.05)$. For Copadichromis species, there were no significant differences $(\mathrm{P}>0.05)$ in the amount of wood used to process a $\mathrm{kg}$ of fish in the frying method $(1.84 \mathrm{~kg})$ against the FRISMO $(1.23 \mathrm{~kg})$ and traditional kilns $(1.42 \mathrm{~kg})$ but differences existed between frying and smoking using the modified kiln $(0.96 \mathrm{~kg})$. However, overall, the modified kiln used the least amount of wood for both species (Table 4).

While the traditional kiln consumed more wood, the FRISMO kiln used $44 \%$ and $13 \%$ less wood to process E. sardella and Copadichromis species, respectively, than that used in the traditional kiln. Less wood (46\% and 32\%) was used in the modified kiln to process E. sardella and Copadichromis species, respectively. Frying, however, did not reduce wood use but rather used higher quantity of wood than that used in the traditional kiln (Figure 1).

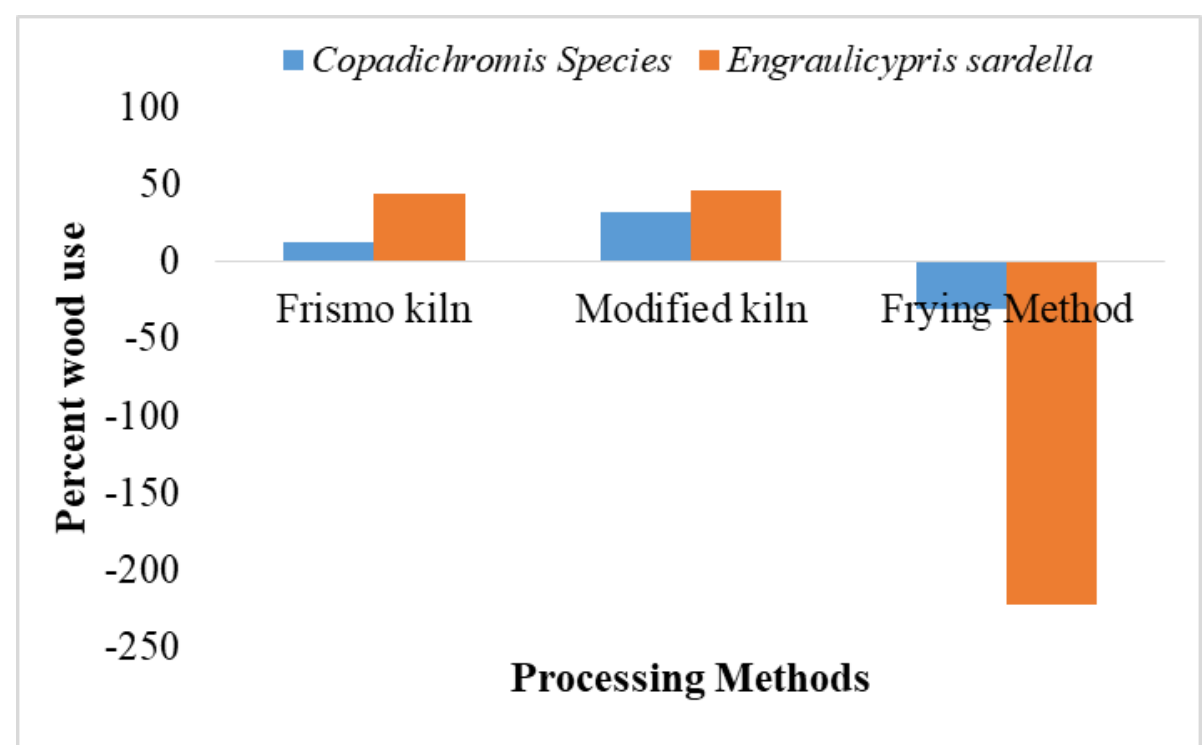

Figure 1: Percent reduction in wood usage for frying, FRISMO and modified kilns against the traditional kiln 


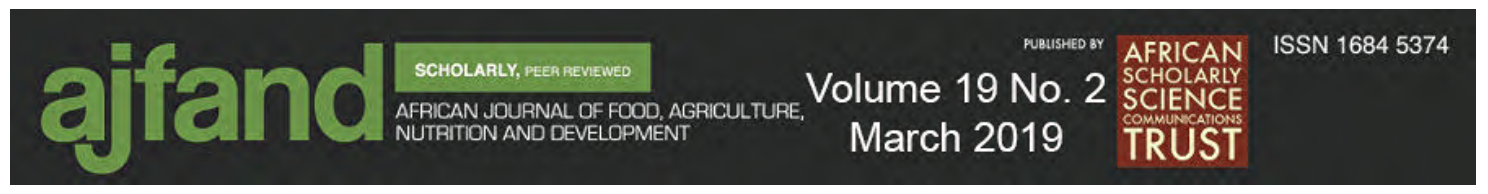

In additional to that, traditional kiln processed least quantity of fish $(0.04-0.06 \mathrm{~kg})$ per minute compared to FRISMO kiln $(0.20-0.23 \mathrm{~kg})$, modified kiln $(0.09-0.14 \mathrm{~kg})$ and frying $(0.17-0.54 \mathrm{~kg})$ (Table 5). The time taken to process Copadichromis species using the frying method was significantly $(<0.05)$ lower $\left(4.2 \pm 0.75^{\mathrm{b}}\right)$ than the time taken to process the same fish by smoking using the traditional kiln $\left(109 \pm 0.32 .97^{\mathrm{a}}\right)$, FRISMO kiln $\left(126 \pm 19.47^{\mathrm{a}}\right)$ and modified kiln $\left(90 \pm 23.98^{\mathrm{a}}\right)$ (Table 5). Similarly, for Engraulicypris sardella, the time taken for frying was significantly $(<0.05)$ lower $\left(4.2 \pm 0.75^{\mathrm{b}}\right)$ than that taken to smoke fish using traditional kiln $\left(66 \pm 8.58^{\mathrm{b}}\right)$, FRISMO kiln $\left(75 \pm 1.92^{\mathrm{a}}\right)$ and modified kiln $\left(60.8 \pm 5.91^{\mathrm{a}}\right)$. However, there were no significant differences $(>0.05)$ in the time taken to process both Engraulicypris sardella and Copadichromis species using the traditional, Frismo and modified kilns.

\section{Acceptability of processed fish in different methods}

The acceptability scores for the processed fish for each method are shown in Table 7. Fried E. sardella had the highest sensory score (7.9) compared to the smoked E. sardella using all smoking methods. For the smoked E. sardella, fish processed in the modified kiln were more preferred (7.8) to those processed using the FRISMO kiln (6.2) and traditional kiln (7.0) with significant differences among the processing methods $(\mathrm{P}<0.05)$. There were no significant differences in acceptability $(\mathrm{P}>0.05)$ between fried (8.3) and smoked (modified kiln $=7.9$, FRISMO kiln $=7.4$ and traditional kiln $=6.1$ ) for Copadichromis species.

In comparing the various smoking technologies, the calculated cost benefit ratio for smoked E. sardella showed a higher cost benefit ratio when using FRISMO (2.3) and modified kiln (2.3) than traditional kiln (2.2) (Table 8). For Copadichromis species, the highest cost benefit ratio was obtained from the FRISMO (2.2) than in the modified (1.9) and traditional kiln (1.9). The highest total cost was incurred in the Modified (MK441, 040.00) compared to the FRISMO (MK180, 889.40) and traditional kiln (MK58, 382.95). However, higher benefits were found in the Modified (MK616, 215.60) and FRISMO (MK509, 437.50) than in the traditional kiln (MK103, 912.50) (Table 9). Higher benefits and gross returns in the FRISMO (MK896, 610.00 and MK523, 359.50) and modified kiln (MK904, 761.00 and MK386, 201.00) than in the traditional kiln (MK317, 850.00 and MK167, 919.20), respectively were also found. On the other hand, the net present value was positive for all kilns (FRISMO (MK1, 910,715), Modified (MK1, 166,327.23) and traditional (MK424, 364.97) kiln) for processing E. sardella.

However, positive net present value was found in using all kiln but was highest in the FRISMO (MK1, 043,771.33) compared to the modified (MK901, 908.85) and traditional kilns (MK123, 676.14). The payback period was attained in the initial year for traditional kiln but in the second year for both FRISMO and modified kilns. The cost benefit ratio of 0.8 was found for fried E. sardella and a ratio of 0.9 was found for frying Copadichromis species (Table 10). 


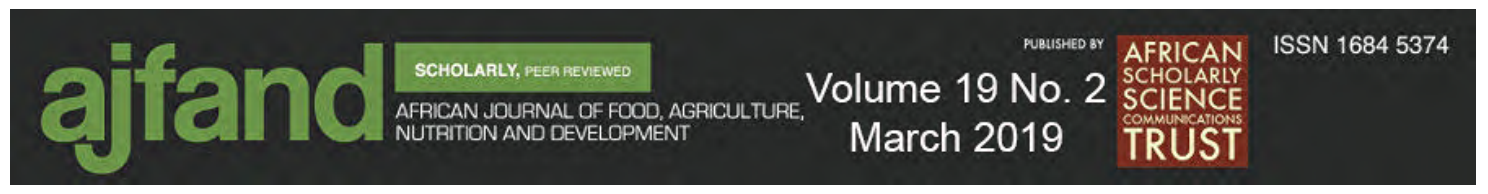

\section{DISCUSSION}

Results showed that the frying method using open fire consumes more wood to process E. sardella than the smoking methods (FRISMO Modified and traditional kilns), due to the fact that cooking oil is boiled for a long time before and during frying unlike in smoking. Secondly, it was observed that the long period (approximately 10 minutes) that is left in between frying, where cooking oil is left to boil again before putting in another bunch of fish also contributed to increased wood usage. This is done to counteract the effect of vaporization as it leads to reduced temperature of the cooking oil in the course of frying [9]. Vaporization is the sudden expulsion of hot steam shooting out of the fish undergoing frying which causes bubbles to appear immediately the fish is put in hot cooking oil. According to Scott [9], vaporization is important for two reasons; the water vapor repels the cooking oil and keeps it from penetrating beyond the surface of the fish. Again, as the steam cools the oil surrounding the fish, it creates time for flavour to develop in the fish suggesting the reason fried fish were liked most. The differences in the moisture level of fish at processing also affect the dehydration rate of fish and directly contributing to the wood consumption during processing. During frying, the surface of the fish dehydrates and leaves behind a crispy crust on the fish as more steam escapes. Once most of the moisture is gone from the outer layer, heat is then able to get to the center of the fish faster. As steam continues to escape, the fish becomes golden brown in colour and this is a signal that the frying is done [9]. Unlike in frying, during smoking, the heat directly from the source dries out the fish surface and dehydration process binds together the aromatic molecules of the smoke to the fish [14]. The dehydration process reacts differently to the moisture level of the fish and hence this is likely to cause variations in the quantity of wood used in frying and smoking using all smoking methods.

Size, shape and form may also affect the kilns efficiency of retaining heat hence affecting the amount of fuel wood used in a particular system as well [6]. During frying, heat loss from open flames may have contributed to the high quantity of wood used in E. sardella as frying is done in an open space. On the other hand, during smoking, fish is enclosed in a chamber, although in the traditional kiln it is semi closed thereby achieving high heat retention resulting into reduced quantity of wood used. The FRISMO and modified kiln had square/rectangular shaped units so that the framed trays could rest flush on the walls leaving some space from the frame wall to the inner wall of the base to prevent heat escape. The trays were fit flush together in order to form a proper chimney which facilitated low energy use of the kilns as recommended by [7].

Colour also plays an important role in the theory of heat absorption of a kiln [15]. White or colours tinted in white have high ability to reflect and transfer heat but off-white colours are suitable for kiln construction to prevent high heat losses during fish processing. The present modified kiln was painted Maroon and the FRISMO kiln was enclosed with bricks on its outer part, hence promoting heating for cooking and smoking E. sardella.

Wood consumption of the smoking kiln is also affected by the heat loss through the walls of the kiln [15]. The amount of heat loss that occur through the walls of a kiln during the firing automatically increases fuel wood consumption. The fact that the modified kiln is 


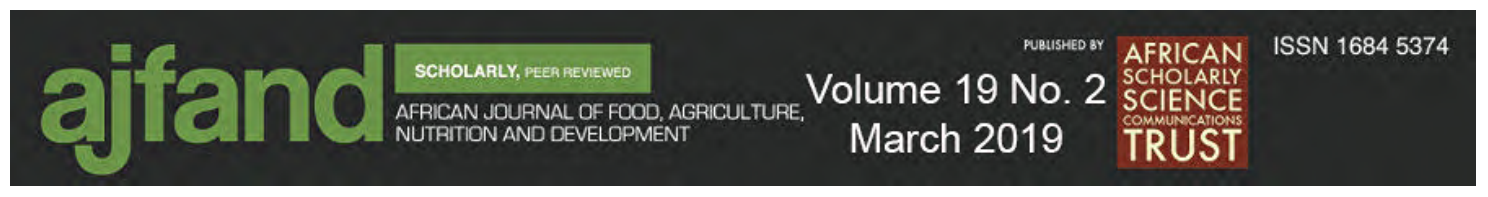

made of metal implies that heat is easily lost in the absence of an insulator. Bolaji [16] reported that kilns that are insulated maintain high temperature, which increases the smoking rate, thereby reducing wood use. The same results would be expected from the FRISMO kiln as it is insulated unlike the modified kiln and traditional kiln. However, contrary results were found where the metal kiln (modified kiln) performed better than the FRISMO kiln. The effective performance of the modified kiln could also be related to the size of fish species. In other places like Nigeria, most processors are keenly aware of the better heat retaining properties of the thick earthen walls like those in the FRISMO kiln as compared to the metal smoking kilns [17]. However, the kilns are mainly used for smoking catfish unlike the smaller species used in the present study. This may imply that kilns without insulators may be good for smaller species unlike the bigger ones.

The traditional kiln used in this study proved not to be climate smart fish processing method due to large quantity of wood used compared to the FRISMO and the modified kilns. In Lake Chilwa, southern Malawi, the FRISMO used 30\% less wood than the traditional kiln to process Barbus species [5], a percentage which was also reported in Ghana for the Chorkor smoker [18]. This is in support of the current results where the traditional kiln proved to be inefficient as compared to the modified and FRISMO kiln to process E. sardella which is almost similar in size to Barbus species. The FRISMO kiln achieved $44 \%$ and $13 \%$ wood use reduction to process E. sardella and Copadichromis species respectively and $46 \%$ and $32 \%$ wood reduction was achieved in the modified kiln to process E. sardella and Copadichromis species respectively in this study.

The inefficiency of the traditional kiln is attributed to its semi closed and openings through which firewood is inserted and kept open throughout the smoking period. Similar findings were reported by Clucas [19] also citing the procedure of smoking using the kiln. The smoking process involves interchanging of trays periodically during processing to avoid burning of the fish. Continuous handling is also done during turning to achieve even distribution of the heat onto the fish for cooking and smoking. The interchanging of the trays causes temperature reduction through the escape of heat to the atmosphere. In the FRISMO and modified kilns, there is little or no interchanging of fish trays hence locking up the heat inside the system.

The variation in performance of the FRISMO, Modified and traditional kilns between $E$. sardella and Copadichromis species could be attributed to the differences in muscle thickness and other biological factors of the fishes. According to the results, the performance of the FRISMO, Modified and traditional kilns using Copadichromis species did not differ and the modified kiln was only unique to the frying method. The initial moisture and fat content of fish for example affects the extent to which wood smoke reacts on the fish during processing [20]. Smoke impacting on the dry surface bounces off because there is nothing to hold it, but the oily and wet surfaces are stickier [20]. Wood smoke is composed of vapours and particles that are easily taken up by the moisture on the fish surface during smoking [21] and the extent of these particles to be imparted onto the surface is dependent on the moisture and fat level. The higher moisture and fat contents in Copadichromis species than E. sardella and may have contributed to the differences in wood consumption between the two species. 


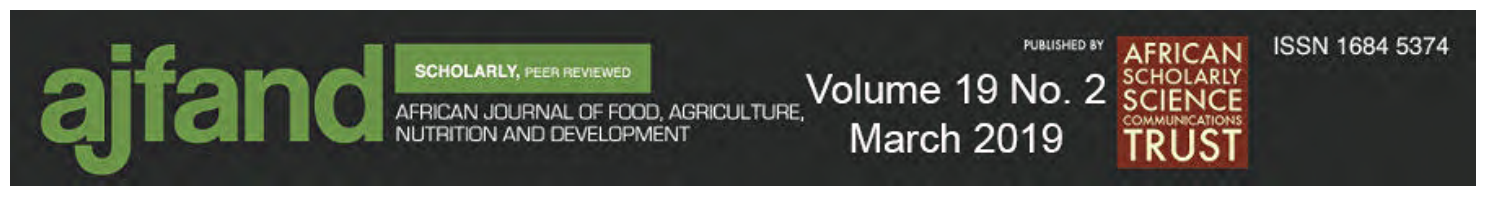

Thermophoresis is also another factor which might have contributed to the differences found between the two species. This is a force that moves particles from a warm to a cold surface during heating [20]. There is a likelihood that the exposure of the fresh fish to the sun for semi drying caused differences in the rise in temperature of the muscles of the E. sardella and Copadichromis species before their exposure to heating from the firewood inside the kilns. As explained earlier, the smoke is easily attracted to colder surfaces than to warmer surfaces due to the effect of thermophoresis. The different muscle sizes between the two species may have caused differences in heating from the sun and hence leading to the differences in wood consumption.

In summary, FRISMO and modified kiln proved to be more efficient in terms of wood usage in processing E. sardella suggesting that they are the best options for environmental sustainability. However, any of the smoking technologies can be used on Copadichromis species since were no significant difference in quantity of wood to be used but use of modified kiln is preferable against the frying method. In Ghana, the simplicity and efficiency in the utilization of fuel wood in an improved smoking kiln called "improved Banda" accelerated its adoption by the local fisher folk [22] by reducing wood usage to $52 \%$ against the traditional kiln. The improved Banda is a modification of the traditional mud-type smoking kiln [23]. The wood saving nature of the FRISMO and modified kiln therefore could assist the fish processors, traders and investors in making their choices. The kilns have also an added advantage of processing a large quantity of fish within a short time which in a way contributes to increased profits as processors can process a lot of fish for sale in a short period. However, frying is the most efficient in saving time as compared to smoking technologies.

Higher acceptability was achieved in the fried fish than smoked products in E. sardella. For the smoked fish, consumers liked more the E. sardella processed in the modified kiln against the products from the traditional and FRISMO kiln Acceptability was indifferent for fried and smoked Copadichromis species. Sensory quality is considered a key factor in food acceptance because consumers look for specified sensory attributes in food chiefly flavour [24]. Knowledge of the consumer acceptability is important because it gives a picture of the possibility for a sustained demand for a particular product if introduced on the market. In the present study, fried E. sardella was highly accepted, which may be due to the special aroma in fried fish which the consumers liked. Frying seems to render a special aroma to fish $[25,26]$. The addition of cooking oil to the fish seems to impart a good flavour which is liked by consumers. Vapourization which occurs in fish during frying is also one of the main contributing factors to the favourable taste of the fish because it promotes development of flavour as earlier explained. Temperature changes that occur in fish and cooking oil during frying add flavour to the fish which consumers like [9]. The higher acceptability in the fried E sardella would positively affect the choice of consumers and therefore, making the products likely to be more marketable. Assessors also liked the flavour of the smoked products mostly for $E$. sardella from the modified kiln as shown by high sensory score. Wood smoke contributes to the good taste of the fish product [24]. A dense smoke atmosphere and conditions where smoke was deposited evenly on the surface of each piece of fish in the modified kiln may have contributed to the good flavour rating. Fish smoking and its 


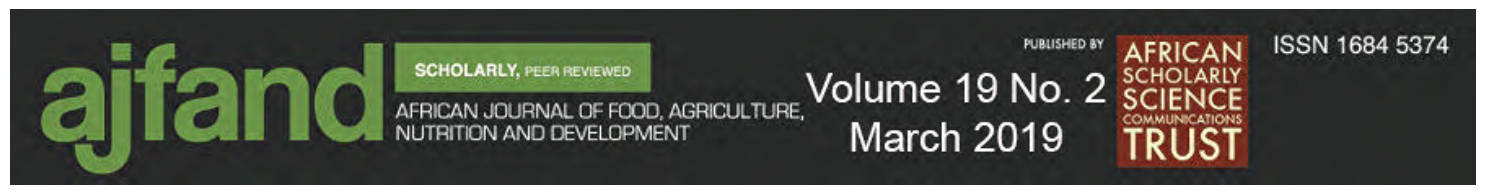

effect have been of interest to several researchers [4, 27] reporting that smoking improves the taste and quality of the fish. The acceptance test in this study earlier recommended by Sidel et al. [28] was used to determine how well the product is liked by consumers.

Choice of a new technology is also influenced by costs. New items for fabricating and constructing a smoking kiln need to be purchased and in so doing money is involved. However, in cases where choices are many, fish processors are likely to be unsure about whether or not, they can recoup the cost of the new technology they would want to adopt or how long it may take to recover the cost of the investment. The profitability and the easiness of the technology to realize the costs invested give an investor the incentive to adopt a technology if it proves profitable for them to do so.

Cost-Benefit Analysis is one of the approaches used to estimate the equivalent money value of the benefits and costs of an investment to establish whether they are worthwhile. According to the principle of cost Benefit analysis, you choose an investment whose ratio is greater than 1 , which simply implies that the investment is able to give more benefits than costs incurred [29]. A cost benefit ratio of 1 shows that the business is in breakeven. This means that it has reached a point at which total cost and total revenue are equal. A ratio of less than 1 indicates that the investment is not profitable and it is not advisable to put money in such an investment. The assessment of cost effectiveness of the FRISMO, Modified and traditional kiln in the present study will assist in decision making of fish processors of whether to adopt a particular technology or not. The highest cost benefit ratio found in FRISMO kiln suggest that it is the best option as it is the most profitable technology to use as compared to the Modified and traditional kiln. On the other hand, frying both E. sardella and Copadichromis species was found not to be profitable.

Studies on cost analysis have been done on new improved technologies against old traditional technologies in some parts of Africa [30, 31, 32]. For instance, Ajang et al. [30] compared cost benefit ratios of using a new improved kiln called "Chorkor smoker" against traditional kiln to provide options for fish processors. From the study, it was found that using the traditional kiln was not as profitable compared to the modified kiln. Earlier studies by Ajang et al. [30], were in agreement to the results found in the present study. In this study, the higher profitability in the FRISMO and modified kiln than the traditional kiln was attributable to longer life span of the kilns than the Traditional kiln with higher discounted net benefits. A similar observation was reported by Arthur [33] where the lifespan of an investment showed to be a contributing factor to its profitability. Adelowo [32] reported similar results when a test was done on improved fish smoker (IFS) against the traditional smoking method. Similar results were found by [30] which found the profitability indices of a Chorkor smoker to be superior over the traditional kiln. High operation costs were noted in frying (MK25, 256.00) which may have led to the negative gross returns in fried Copadichromis species. Again, the high cost of cooking oil contributed to the higher cost in both E. sardella and Copadichromis species. The higher benefits in both cases suggest that the better selling price of fish obtained from frying did not necessarily lead to higher profitability. 


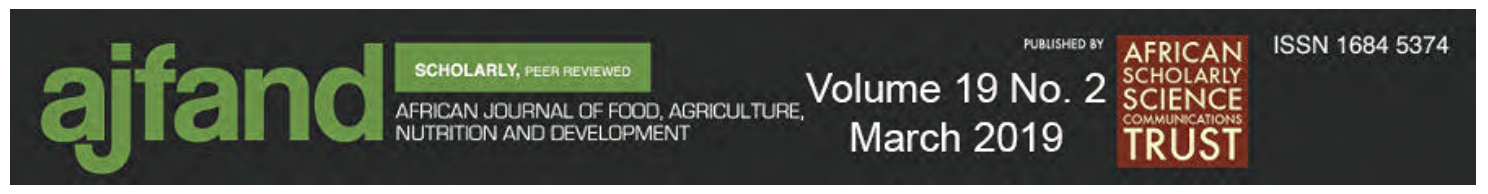

\section{CONCLUSION}

The study found the Modified and FRISMO kilns to be more efficient in wood usage when processing E. sardella. Same wood utilization efficiency was reported for Copadichromis species in all methods hence reducing contribution of fish smoking to forest depletion. E. sardella and Copadichromis species smoked in both smoking methods were highly accepted while fried E. sardella and Copadichromis species were preferred most. However, low profitability was found for the frying method as compared to the rest of the smoking technologies and a lower profitability in traditional kiln than in the FRISMO and modified kiln. It is recommended therefore that the Modified and FRISMO kilns should be promoted for adoption for processing fish species smaller in size like E. sardella and Copadichromis species due to low usage of wood, high consumer acceptance and contribution to environmental sustainability as well as due to their high profitability. Upcoming improved fish processing technologies should also be made to be mobile like the modified kiln but should also have heat insulators to avoid loss of heat which in turn will reduce further the quantity of wood used. The technologies should also be made in such a way that there is no or minimal handling of fish during processing as these present challenges in terms of preference by the end users.

\section{ACKNOWLEDGEMENTS}

Authors would like to acknowledge the David Livingstone Bicentenary Scholarships and Capacity Building for Managing Climate Change in Malawi Programme (CABMACC) through the Sustainable Environment and Enterprise Development for climate change adaptation in Fisheries (SEED-Fish) Project for their financial support. Our appreciation also goes to the Department of Aquaculture and Fisheries Science at Bunda College, staff of NEPAD Regional Fish Node at the Lilongwe University of Agriculture and Natural Resources (LUANAR) and the Laboratory Technician at Bunda College - Mr. E. Nyali. The District Fisheries Officer for Nkhotakota District Mr. R. Makwinja and his staff, fish processors and all assessors involved in the study deserve our appreciation. 


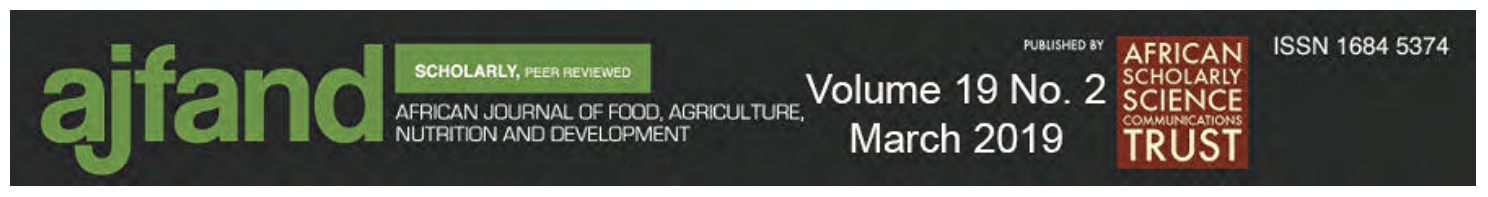

Table 1: Weight (in kg) of fish loaded in each smoking kiln during one cycle of fish processing

\begin{tabular}{lcc}
\hline Smoking method & Engraulicypris sardella fish & Copadichromis species fish \\
\hline FRISMO kiln & 35 & 31.5 \\
Modified kiln & 20 & 17.5 \\
Traditional kiln & 8 & 13 \\
\hline
\end{tabular}

Table 2: Differences in moisture and fat contents between fresh Copadichromis species and Engraulicypris sardella

\begin{tabular}{lcc}
\hline Species & Moisture content & Fat content \\
\hline Engraulicypris sardella & $57.3 \pm 0.58^{\mathrm{b}}$ & $13.7 \pm 0.11^{\mathrm{a}}$ \\
Copadichromis species & $60.3 \pm 2.89^{\mathrm{a}}$ & $9.7 \pm 3.23^{\mathrm{b}}$ \\
\hline \multicolumn{2}{l}{ Means with same superscripts in columns are not significantly different $(P>0.05)$, Mean $\pm \mathrm{SE}$}
\end{tabular}




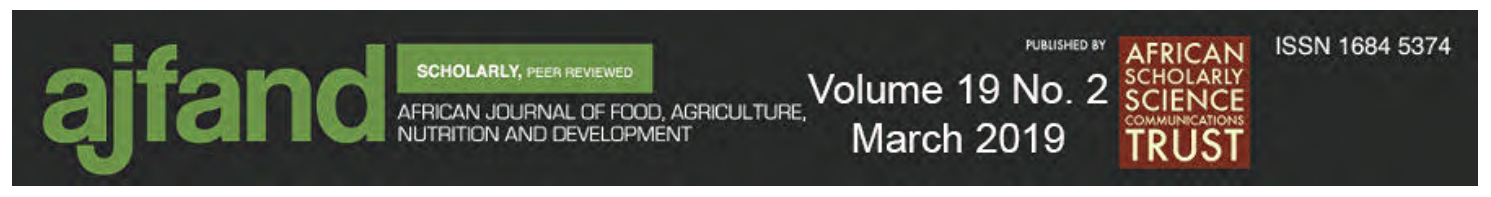

Table 3: Assumptions in computing cost benefit analysis

\begin{tabular}{|c|c|c|c|c|}
\hline \multirow[b]{2}{*}{ Parameters } & \multicolumn{3}{|c|}{ Type of technology } & \multirow[b]{2}{*}{$\begin{array}{l}\text { Basis for the information } \\
\text { and assumptions }\end{array}$} \\
\hline & FRISMO kiln & $\begin{array}{l}\text { Traditional } \\
\text { kiln }\end{array}$ & $\begin{array}{l}\text { Modified } \\
\text { kiln }\end{array}$ & \\
\hline $\begin{array}{l}\text { Life span of smoking } \\
\text { structure }\end{array}$ & 5 Years & 2 years & 3 years & $\begin{array}{l}\text { Conclusion made from } \\
\text { literature and estimations by } \\
\text { the targeted users }\end{array}$ \\
\hline $\begin{array}{l}\text { Number of smoking } \\
\text { cycles/per day }\end{array}$ & 10 & 12 & 12 & Direct observation \\
\hline Rental fees & MK1, 160.00 & MK470.00 & MK1,030.00 & $\begin{array}{l}\text { Suggested by the targeted end } \\
\text { users }\end{array}$ \\
\hline $\begin{array}{l}\text { Maximum weight of fish } \\
\text { per kiln }\end{array}$ & $35 \mathrm{~kg}$ & $13 \mathrm{~kg}$ & $20 \mathrm{~kg}$ & $\begin{array}{l}\text { Calculated from possible fish } \\
\text { loadings into the kilns }\end{array}$ \\
\hline Lending interest rate & $24 \%$ p.a & $24 \%$ p.a & $24 \%$ p.a & $\begin{array}{l}\text { Adopted from the national } \\
\text { interest rate }\end{array}$ \\
\hline $\begin{array}{l}\text { Maximum number of trays } \\
\text { on the oven }\end{array}$ & 7 & 2 & 5 & Observation \\
\hline Depreciation & $20 \%$ & $50 \%$ & $33 \%$ & $\begin{array}{l}\text { Calculated with reference to } \\
\text { the shelf life of the kiln }\end{array}$ \\
\hline
\end{tabular}

Table 4: Quantity of wood (Kg) used to process a kilogram of fish using different processing methods

\begin{tabular}{|c|c|c|c|c|c|}
\hline \multirow[t]{2}{*}{ Species } & \multicolumn{4}{|c|}{ Processing Method } & \multirow{2}{*}{$\begin{array}{c}P \\
\text { value }\end{array}$} \\
\hline & $\begin{array}{c}\text { Traditional } \\
\text { kiln }\end{array}$ & $\begin{array}{c}\text { FRISMO } \\
\text { kiln }\end{array}$ & $\begin{array}{l}\text { Modified } \\
\text { kiln }\end{array}$ & Frying & \\
\hline Copadichromis & $1.41 \pm 0.17^{\mathrm{ab}}$ & $1.23 \pm 0.06^{\mathrm{ab}}$ & $0.96 \pm 0.14^{a}$ & $1.84 \pm 0.29^{b}$ & .056 \\
\hline E. sardella & $1.81 \pm 0.15^{\mathrm{b}}$ & $1.01 \pm 0.17^{\mathrm{a}}$ & $0.98 \pm 0.07^{\mathrm{a}}$ & $5.82 \pm 0.20^{\mathrm{c}}$ & .000 \\
\hline
\end{tabular}

Means with same superscripts in the same row are not significantly different $(\mathrm{P}>0.05)$ 


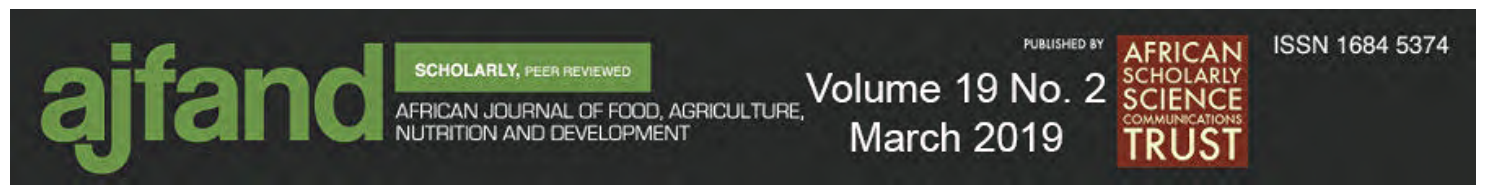

Table 5: Differences in weight of fish (in kilograms) processed per minute for Engraulicypris sardella and Copadichromis species

\begin{tabular}{lcc}
\hline Type of technology & Engraulicypris sardella & Copadichromis species \\
\hline Traditional & $0.04 \pm 0.01^{\mathrm{a}}$ & $0.06 \pm 0.01^{\mathrm{a}}$ \\
FRISMO & $0.20 \pm 0.01^{\mathrm{ab}}$ & $0.23 \pm 0.06^{\mathrm{a}}$ \\
Modified & $0.09 \pm 0.02^{\mathrm{b}}$ & $0.14 \pm 0.04^{\mathrm{a}}$ \\
Frying & $0.17 \pm 0.04^{\mathrm{b}}$ & $0.54 \pm 0.51^{\mathrm{a}}$ \\
P value & 0.04 & 0.18
\end{tabular}

Means with same superscripts are not significantly different $(\mathrm{P}>0.05)$, Mean $\pm \mathrm{SE}$

Table 6: Differences in the time taken to smoke fish in different smoking kilns (under the temperature of $52^{\circ} \mathrm{C}-73^{\circ} \mathrm{C}$ ) and to fry fish at $190^{\circ} \mathrm{C}$

\begin{tabular}{lccccc}
\hline \multirow{2}{*}{ Species } & \multicolumn{5}{c}{ Time taken (in minutes) } \\
\cline { 2 - 6 } & $\begin{array}{c}\text { Traditional } \\
\text { kiln }\end{array}$ & $\begin{array}{c}\text { FRISMO } \\
\text { kiln }\end{array}$ & $\begin{array}{c}\text { Modified } \\
\text { kiln }\end{array}$ & Frying & $\begin{array}{c}\text { P } \\
\text { value }\end{array}$ \\
\hline Copadichromis species & $109 \pm 0.32 .97^{\mathrm{a}}$ & $126 \pm 19.5^{\mathrm{a}}$ & $90 \pm 2.3^{\mathrm{a}}$ & $9 \pm 1.3^{\mathrm{b}}$ & 0.015 \\
Engraulicypris sardella & $66 \pm 8.6^{\mathrm{b}}$ & $75 \pm 1.9^{\mathrm{a}}$ & $60.8 \pm 5.9^{\mathrm{a}}$ & $4.2 \pm 0.8^{\mathrm{b}}$ & $<0.001$ \\
\hline
\end{tabular}

Table 7: Mean sensory scores of smoked and fried Engraulicypris sardella and Copadichromis species

\begin{tabular}{|c|c|c|c|c|c|}
\hline \multirow{2}{*}{ Species } & \multicolumn{4}{|c|}{ Processing Method } & \multirow{2}{*}{$P$ value } \\
\hline & Fried & Modified & Traditional & FRISMO kiln & \\
\hline E. Sardella & $7.9 \pm 0.2^{a}$ & $7.75 \pm 0.2^{\mathrm{bc}}$ & $7.0 \pm 0.2^{b}$ & $6.2 \pm 0.2^{\mathrm{a}}$ & 0.000 \\
\hline Copadichromis & $8.3 \pm 0.2^{c}$ & $7.8 \pm 0.2^{\mathrm{bc}}$ & $6.1 \pm 0.2^{\mathrm{a}}$ & $7.4 \pm 0.2^{b}$ & 0.000 \\
\hline
\end{tabular}

Means with same superscripts are not significantly different $(\mathrm{P}>0.05)$ 


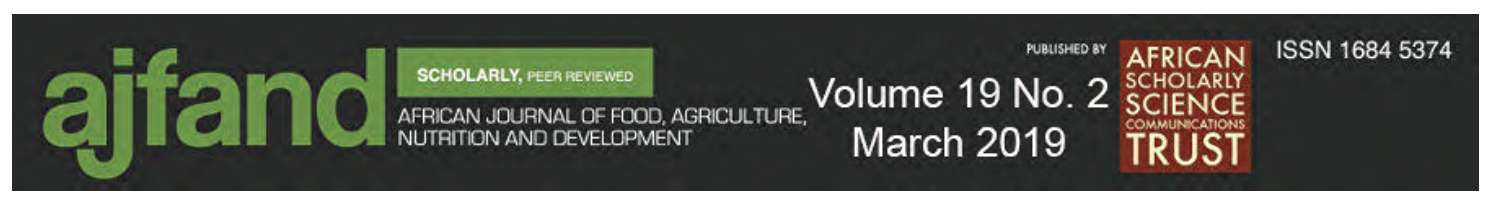

Table 8: Financial analysis of Engraulicypris sardella smoked in a FRISMO, Modified and Traditional kiln in Malawi Kwacha (MK) (MK710 is equivalent to 1 US Dollar)

\begin{tabular}{|c|c|c|c|c|c|c|c|c|c|c|c|c|c|}
\hline \multirow[b]{2}{*}{ Years } & \multicolumn{3}{|c|}{ traditional kiln } & \multicolumn{6}{|c|}{ FRISMO kiln } & \multicolumn{4}{|c|}{ modified kiln } \\
\hline & 0 & 1 & 2 & 0 & 1 & 2 & 3 & 4 & 5 & 0 & 1 & 2 & 3 \\
\hline \multicolumn{14}{|l|}{ Fixed Cost } \\
\hline Smoking Oven & 2200 & & & 205460 & & & & & & 246000 & & & \\
\hline Plywood cover & 4675 & & & & & & & & & & & & \\
\hline Smoking trays & 9350 & & & 28,000 & & & & & & 40,000 & & & \\
\hline Total Fixed Cost & 16225 & $\mathbf{0}$ & $\mathbf{0}$ & 233460 & $\mathbf{0}$ & $\mathbf{0}$ & $\mathbf{0}$ & $\mathbf{0}$ & $\mathbf{0}$ & 286000 & $\mathbf{0}$ & $\mathbf{0}$ & $\mathbf{0}$ \\
\hline \multicolumn{14}{|l|}{ Variable cost } \\
\hline Fresh Fish & 57408 & 57408 & 57408 & 207900 & 207900 & 207900 & 207900 & 207900 & 207900 & 142560 & 142560 & 142560 & 142560 \\
\hline Firewood & 10800 & 10800 & 10800 & 20000 & 20000 & 20000 & 20000 & 20000 & 20000 & 18000 & 18000 & 18000 & 18000 \\
\hline wages for labour & 5498 & 5498 & 5498 & 12000 & 12000 & 12000 & 12000 & 12000 & 12000 & 12000 & 12000 & 12000 & 12000 \\
\hline Transport & 60000 & 60000 & 60000 & 50000 & 50000 & 50000 & 50000 & 50000 & 50000 & 60000 & 60000 & 60000 & 60000 \\
\hline Depreciation & & 8113 & 8113 & & 46692 & 46692 & 46692 & 46692 & 46692 & & 94380 & 94380 & 94380 \\
\hline Total variable Costs & 133706 & 141818 & 141818 & 289900 & 336592 & 336592 & 336592 & 336592 & 336592 & 232560 & 326940 & 326940 & 326940 \\
\hline Total cost & 149931 & 141818 & 141818 & 523360 & 336592 & 336592 & 336592 & 336592 & 336592 & 518560 & 326940 & 326940 & 326940 \\
\hline \multicolumn{14}{|l|}{ Benefits } \\
\hline Smoked Fish & 317850 & 317850 & 317850 & 896610 & 896610 & 896610 & 896610 & 896610 & 896610 & 904761 & 904761 & 904761 & 904761 \\
\hline Discounted benefits & 317850 & 256331 & 206718 & 896610 & 723073 & 583123 & 470261 & 379242 & 305841 & 904761 & 729646 & 588424 & 474536 \\
\hline $\begin{array}{l}\text { Total discounted } \\
\text { benefits }\end{array}$ & 780899 & & & 3358149 & & & & & & 2697367 & & & \\
\hline \multicolumn{14}{|l|}{ Interest payment } \\
\hline $\begin{array}{l}\text { Operation costs(interest } \\
\text { rate) }\end{array}$ & $24 \%$ & $24 \%$ & $24 \%$ & $24 \%$ & $24 \%$ & $24 \%$ & $24 \%$ & $24 \%$ & $24 \%$ & $24 \%$ & $24 \%$ & $24 \%$ & $24 \%$ \\
\hline Fixed cost (interest rate) & $24 \%$ & $24 \%$ & $24 \%$ & $24 \%$ & $24 \%$ & $24 \%$ & $24 \%$ & $24 \%$ & $24 \%$ & $24 \%$ & $24 \%$ & $24 \%$ & $24 \%$ \\
\hline Gross Returns & 167919 & 176032 & 176032 & 373251 & 560018 & 560018 & 560018 & 560018 & 560018 & 386201 & 577821 & 577821 & 577821 \\
\hline Discounted Net benefits & 167919 & 141961 & 114485 & 373251 & 451628 & 364216 & 293722 & 236873 & 191027 & 386201 & 465985 & 375794 & 303060 \\
\hline $\begin{array}{l}\text { Total discounted net } \\
\text { benefits }\end{array}$ & 424365 & & & 1910715 & & & & & & 1531040 & & & \\
\hline Discounted costs & 133706 & 114370 & 92234 & 289900 & 271445 & 218907 & 176538 & 142370 & 114814 & 232560 & & 212630 & 171476 \\
\hline Total discounted costs & 356534 & & & 1447434 & & & & & & 1166327 & & & \\
\hline Payback & 167919 & 309880 & 424365 & 373251 & 824878 & 1189094 & 1482816 & 1719689 & 1910715 & 386201 & 852186 & 1227980 & 1531040 \\
\hline Net Present Value & 424365 & & & 1910715 & & & & & & 1531040 & & & \\
\hline Cost Benefit Ratio & 2.2 & & & 2.3 & & & & & & 2.31 & & & \\
\hline
\end{tabular}




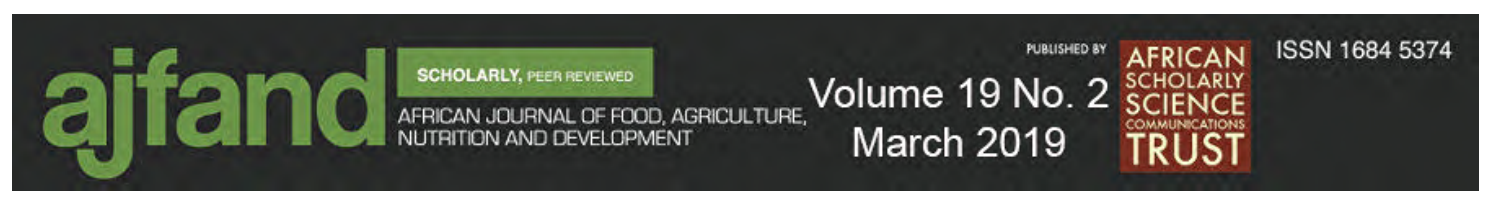

Table 9: Financial analysis of Copadichromis species smoked in a FRISMO, Modified and Traditional kiln in Malawi Kwacha (MK) (MK710 is equivalent to 1 US Dollar)

\begin{tabular}{|c|c|c|c|c|c|c|c|c|c|c|c|c|c|}
\hline \multirow[b]{2}{*}{ Years } & \multicolumn{3}{|c|}{ traditional kiln } & \multicolumn{6}{|c|}{ FRISMO kiln } & \multicolumn{4}{|c|}{ Modified kiln } \\
\hline & $\mathbf{0}$ & 1 & 2 & $\mathbf{0}$ & 1 & 2 & 3 & 4 & 5 & $\mathbf{0}$ & 1 & 2 & 3 \\
\hline \multicolumn{14}{|l|}{ Fixed Cost } \\
\hline Smoking Oven & 2200 & & & 205460 & & & & & & 246000 & & & \\
\hline Plywood cover & 4675 & & & & & & & & & & & & \\
\hline Smoking trays & 9350 & & & 28,000 & & & & & & 40,000 & & & \\
\hline Total Fixed Cost & 16225 & $\mathbf{0}$ & $\mathbf{0}$ & 233460 & $\mathbf{0}$ & $\mathbf{0}$ & $\mathbf{0}$ & $\mathbf{0}$ & $\mathbf{0}$ & 286000 & $\mathbf{0}$ & $\mathbf{0}$ & $\mathbf{0}$ \\
\hline \multicolumn{14}{|l|}{ Variable cost } \\
\hline Fresh Fish & 23084 & 23084 & 23084 & 93198 & 93198 & 93198 & 93198 & 93198 & 93198 & 95040 & 95040 & 95040 & 95040 \\
\hline Firewood & 2700 & 2700 & 2700 & 10000 & 10000 & 10000 & 10000 & 10000 & 10000 & 12000 & 12000 & 12000 & 12000 \\
\hline wages for labor & 1374 & 1374 & 1374 & 6000 & 6000 & 6000 & 6000 & 6000 & 6000 & 8000 & 8000 & 8000 & 8000 \\
\hline Transport & 15000 & 15000 & 15000 & 25000 & 25000 & 25000 & 25000 & 25000 & 25000 & 40000 & 40000 & 40000 & 40000 \\
\hline Depreciation & & 8113 & 8113 & & 46692 & 46692 & 46692 & 46692 & 46692 & & 94380 & 94380 & 94380 \\
\hline Total variable Costs & 42158 & 50270 & 50270 & 134198 & 180889 & 180889 & 180889 & 180889 & 180889 & 155040 & 249420 & 249420 & 249420 \\
\hline Total cost & 58383 & 50270 & 50270 & 367657 & 180889 & 180889 & 180889 & 180889 & 180889 & 441040 & 249420 & 249420 & 249420 \\
\hline \multicolumn{14}{|l|}{ Benefits } \\
\hline Smoked Fish & 103913 & 103913 & 103913 & 509438 & 509438 & 509438 & 509438 & 509438 & 509438 & 616216 & 616216 & 616216 & 616216 \\
\hline Discounted benefits & 103913 & 83800 & 67581 & 509438 & 410837 & 331320 & 267193 & 215479 & 173773 & 616216 & 496948 & 400765 & 323197 \\
\hline Total discounted benefits & 255294 & & & 1908039 & & & & & & 1837125 & & & \\
\hline \multicolumn{14}{|l|}{ Interest payment } \\
\hline $\begin{array}{l}\text { Operation costs } \\
\text { (interest rate) }\end{array}$ & $24 \%$ & $24 \%$ & $24 \%$ & $24 \%$ & $24 \%$ & $24 \%$ & $24 \%$ & $24 \%$ & $24 \%$ & $24 \%$ & $24 \%$ & $24 \%$ & $24 \%$ \\
\hline Gross Returns & 45530 & 53642 & 53642 & 141780 & 328548 & 328548 & 328548 & 328548 & 328548 & 175176 & 366796 & 366796 & 366796 \\
\hline Discounted Net benefits & 45530 & 43260 & 34887 & 141781 & 264958 & 213676 & 172319 & 138967 & 112070 & 175176 & 295803 & 238551 & 192380 \\
\hline $\begin{array}{l}\text { Total discounted net } \\
\text { benefits }\end{array}$ & 123676 & & & 1043771 & & & & & & 901909 & & & \\
\hline Discounted costs & 42158 & 40541 & 32694 & 134198 & 145879 & 117644 & 94874 & 76511 & 61703 & 155040 & 201145 & 162214 & 130818 \\
\hline Total discounted costs & 131618 & & & 864268 & & & & & & 935217 & & & \\
\hline Payback & 45530 & 88789 & 123676 & 141781 & 406739 & 620415 & 792734 & 931701 & 1043771 & 175176 & 470979 & 709529 & 901909 \\
\hline Net Present Value & 123,676 & & & $1,043,771$ & & & & & & 901,909 & & & \\
\hline Cost Benefit Ratio & 2.0 & & & 2.2 & & & & & & 2.0 & & & \\
\hline
\end{tabular}




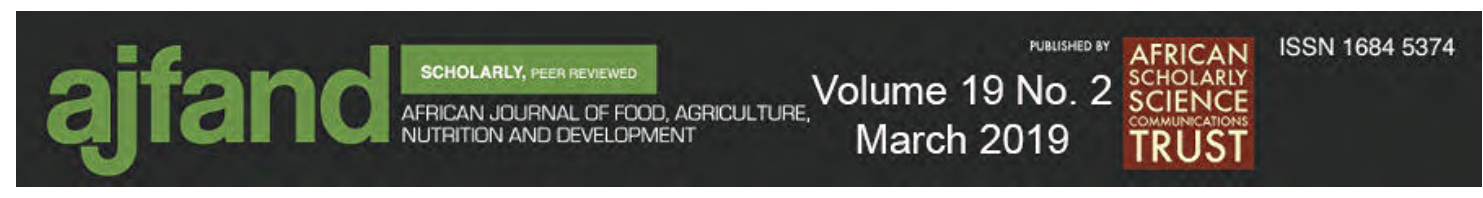

Table 10: Cost benefit analysis of frying Engraulicypris sardella and Copadichromis species (MK710 is equivalent to 1 US Dollar)

\begin{tabular}{|c|c|c|c|c|}
\hline \multirow[b]{2}{*}{ Expenditure } & \multicolumn{4}{|c|}{ Species of fish } \\
\hline & $\begin{array}{l}\text { Copadichromis } \\
\text { species (MK) }\end{array}$ & $\begin{array}{c}\text { Copadichromis } \\
\text { species (US\$) }\end{array}$ & $\begin{array}{c}\text { Engraulicypris } \\
\text { sardella (MK) }\end{array}$ & $\begin{array}{l}\text { Engraulicypris } \\
\text { sardella (US\$) }\end{array}$ \\
\hline Transport & 5000 & 7.04 & 5000 & 7.04 \\
\hline Firewood & 2706 & 3.81 & 2706 & 3.81 \\
\hline Accommodation & 1000 & 1.41 & 1000 & 1.41 \\
\hline Drying rank & 700 & 0.99 & 700 & 0.99 \\
\hline Frying Pan & 700 & 0.99 & 700 & 0.99 \\
\hline Cooking oil & 7750 & 10.92 & 7000 & 9.86 \\
\hline Labour & 500 & 0.70 & 500 & 0.70 \\
\hline Spoons & 600 & 0.85 & 600 & 0.85 \\
\hline Fresh fish & 11300 & 15.92 & 11300 & 15.92 \\
\hline Total cost & 25256 & 35.57 & 29506 & 41.56 \\
\hline \multicolumn{5}{|l|}{ Benefits (income) } \\
\hline Fried Fish & 26900 & 37.89 & 25000 & 35.21 \\
\hline Discounted benefits & 26900 & 37.89 & 25000 & 35.21 \\
\hline \multicolumn{5}{|l|}{ Interest payment } \\
\hline $\begin{array}{l}\text { Operation Costs (interest } \\
\text { rate) }\end{array}$ & 0.24 & & 0.24 & 0.24 \\
\hline Fixed cost (interest rate) & 0.24 & & 0.24 & 0.24 \\
\hline Gross Returns & -2607 & -3.67 & -4506 & -6.35 \\
\hline Discounted Net benefits & -2607 & -3.67 & -4506 & -6.35 \\
\hline Total discounted costs & 29507 & 41.56 & 29506 & 41.56 \\
\hline Cost Benefit Ratio & 0.9116 & 0.9116 & 0.8473 & 0.8473 \\
\hline
\end{tabular}




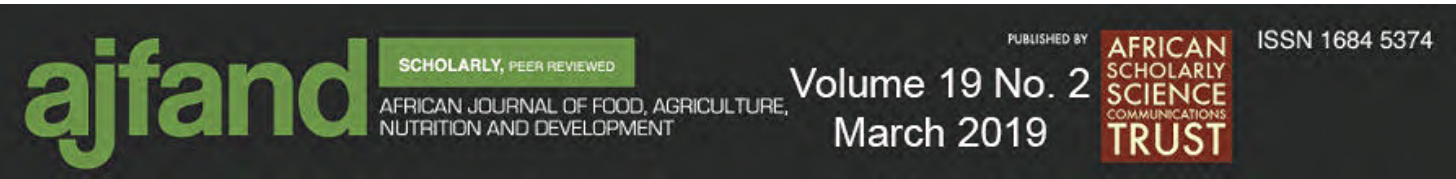

\section{REFERENCES}

1. FAO. A synthesis report on technical assistance and investment. Rome 2010. Available at http://www.fao.org/docrep/field/003/AC112E/AC112E00.html. Accessed 10/07/2018

2. Scholtz U, Njaya FJ, Chimatiro S, Hummel M, Donda $\mathbf{S}$ and BJ Mkoko Status and prospects of participatory fisheries management programs in Malawi. Inland Fishery Enhancements 1998; (374): 407.

3. Diei-Ouadi Y and YI Mgawe Post-harvest fish loss assessment in small-scale fisheries: A guide for the extension officer. FAO Fisheries and Aquaculture Technical Paper No. 559. Rome, Italy. 2011; 93.

4. Ahmed A, Dodo A, Bouba A, Clement S and T Dzudie Influence of traditional drying and smoke-drying on the quality of three fish species from Lagdo Lake, Cameroon. Journal of Animal Veterinary Advances 2011; 10(3): 301-306.

5. Luhanga D and D Jamu A review of fuel saving technologies and alternative energy sources in Lake Chilwa basin, 2012 (personal communication)".

6. FAO. The State of World Fisheries and Aquaculture. FAO Fisheries and Aquaculture Department, Food and Agriculture Organization of the UN, Rome 2010.

7. Brownell B and J Lopez The Chorkor fish smoking method: a truly appropriate technology. FAO Fisheries Report 1986.

8. Kapute F, Singini W, Valeta J and J Kamanga Sustainable environment and enterprise development for climate change adaptation in fisheries (SEED-Fish) baseline report. Lilongwe University of Agriculture and Natural Resources. 2015. Personal communication.

9. Scott L Sober Kitchen: Recipes and Advice for a Lifetime of Sobriety. Harvard Common Press. United States of America, 2003.

10. Macrae JD and JH Kenneth Comparison of methods used to determine the availability of polycyclic aromatic hydrocarbons in marine sediment. 2010; 32(23): 3809-3815.

11. Association of Official Analytical Chemists Official methods of Analysis of the AOAC International. 20th ed. Rockville, Maryland: Association of Official Analytical Chemists Inc. 2016.

12. Chilora B Research on new fuel wood saving fish smoking kiln for adoption by rural fish farmers and fishermen. Malawi College of Fisheries, Mangochi 2012. (Personal communication).

13. Joram A and F Kapute Sensory evaluation of wild-captured and pond-raised Tilapias in Malawi. African Journal of Food Science 2016; 10(10): 238-242. 


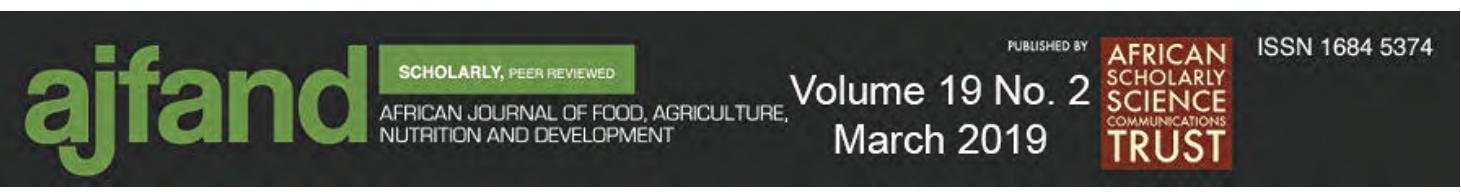

14. Bergmann A and O Melander Investors; Shingotec assignee: Method for predicting the risk of getting cancer or diagnosing cancer in a female subject. United States patent application us 2013; 14/383: 428.

15. Rhodes D Kiln Design, Construction and Operation. Pitman Publishing Corporation 1968. New York.

16. Bolaji BO Performance evaluation of a simple solar dryer for food preservation. Book of Proceedings of $6^{\text {th }}$ Annual Engineering Technology, Federal University of Technology, Minna, Nigeria, 2005; 8-13.

17. Smith D An online interactive thematic mapping: Applications and techniques for socioeconomic research. Computers, Environment and Urban Systems 2016; 57:106-117.

18. Date-Bah E Rural Women, their activities and technology in Ghana: an overview. ILO, 1981.

19. Clucas IJ Fish handling, processing and preservation in the Tropics. Report of the Tropical Products Institute, London. G144. 1982; Part 2:145.

20. Blonde L, Dempster J, Gallivan JM and $\mathbf{E}$ Warren-Boulton Reducing cardiovascular disease risk in patients with diabetes: Diabetes Program. Journal of the American Academy of Nurse Practitioners, 2006; 18(11): 524-533.

21. Knowles ME, Gilbert J and JM David Phenols in smoked cured meats. Phenolic composition of commercial liquid smoke preparations and derived bacon. Journal of the Science of Food and Agriculture1975; 26(2): 189-196.

22. Eyo AA Traditional and improved fish handling, preservation and processing Techniques. Paper presented at National workshop on fish processing storage, marketing and utilization in Ghana 1993.

23. Adelowo EO, Okomoda JK and AA Eyo Construction, extension and evaluation of the improved smoking kiln (Banda) In Kainji Lake area. In: $16^{\text {th }}$ Annual conference of the fisheries society of Nigeria (FISION), Maiduguri, Nigeria, 2001: 250-255.

24. Costell E, Tárrega A and S Bayarri Food acceptance: the role of consumer perception and attitudes." Chemosensory Perception 2010; 3(1):42-50.

25. Holma KA and BK Maalekuu Effect of traditional fish processing methods on the proximate composition of red fish stored under ambient room conditions. American Journal of Food and Nutrition 2013; 3: 73-82.

26. Gere A Studies of the changes in edible fats during heating and frying. Food/Nahrung1982; 26(10): 923-932. 


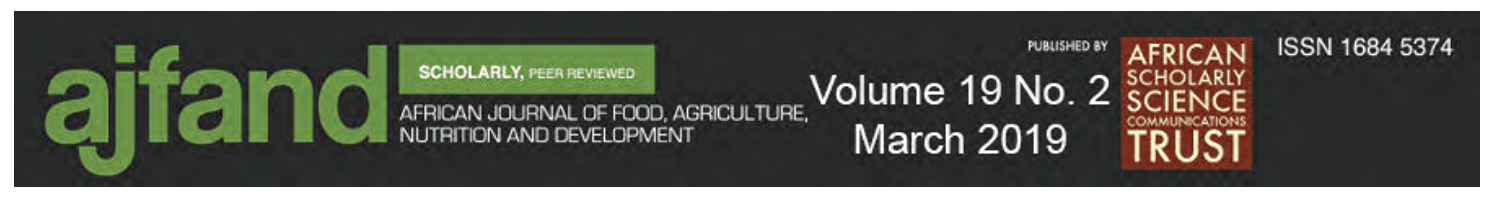

27. Aminullah-Bhugan AKM, Ratnayake WMN and RG Ackman Effect of smoking on proximate composition of Atlantic Mackerel. Journal of Food Science 2006; 51(2):327-329.

28. Sidel JL, Stone $\mathbf{H}$ and $\mathbf{J}$ Bloomquist Use and misuse of sensory evaluation in research and quality control. Journal of dairy Science 1981; 64(11): 2296-2302.

29. Layard R and S Glaister Cost-benefit analysis. Cambridge University Press 1994.

30. Ajang RO, Ndome CB and RU Ingwe Cost-Benefit Analysis of Chorkor and Traditional Smoking Kilns for Fish Processing. Iranica Journal of Energy and Environment 2010; 1(4): 339-346.

31. Allou K, Issali AE, Lekadou T, Konan KJL, Zakra N, Kouassi KP, Bourdeix R, Morin JP and YDM Saraka Comparative synergetic effect of coconut palm (Cocos nucifera L.) slices and bunches residue of oil palm (Elaeis guineensis) associated with two kinds of pheromone traps on Oryctes monoceros trapping in Côte d'Ivoire. International Journal of Emerging Technology and Advanced Engineering 2012; 2(6): 1-6.

32. Adelowo ME The influence of social studies on students' attitudes towards cultivating positive human relationships: A study of some selected secondary schools in Jos North LGA, Plateau State. M. Ed. Thesis, University of Jos, Nigeria 1998.

33. Arthur WB Competing technologies, increasing returns and lock-in by historical events. The Economic Journal 1989; 99(394): 116-131. 